\section{A) Check for updates}

Cite this: Org. Biomol. Chem., 2020, 18,5253

Received 17th April 2020, Accepted 23rd June 2020

DOI: $10.1039 / \mathrm{d} 0 \mathrm{ob} 00799 \mathrm{~d}$ rsc.li/obc

\title{
Dimerization of conserved ascaroside building blocks generates species-specific male attractants in Caenorhabditis nematodes $\dagger$
}

\author{
Chuanfu Dong, (D) $\$ \S^{\mathrm{a}}$ Franziska Dolke, $\ddagger^{\mathrm{a}}$ Siva Bandi, (D) ${ }^{\mathrm{b}}$ Christian Paetz (D) ${ }^{\mathrm{c}}$ and \\ Stephan H. von Reuß (D)*a,b
} \begin{abstract}
Comparative ascaroside profiling of Caenorhabditis nematodes using HPLC-ESI-(-)-MS/MS precursor ion
scanning revealed a class of highly species-specific ascaroside dimers. Their 2- and 4-isomeric, homo-
and heterodimeric structures were identified using a combination of HPLC-ESI-(+)-HR-MS/MS spectrometry
and high-resolution dqf-COSY NMR spectroscopy. Structure assignments were confirmed by total synthesis
of representative examples. Functional characterization using holding assays indicated that males of
Caenorhabditis remanei and Caenorhabditis nigoni are exclusively retained by their conspecific ascaroside
dimers, demonstrating that dimerization of conserved monomeric building blocks represents a yet unde-
scribed mechanism that generates species-specific signaling molecules in the Caenorhabditis genus. Comparative ascaroside profiling of Caenorhabditis nematodes using HPLC-ESI-(-)-MS/MS precursor ion
scanning revealed a class of highly species-specific ascaroside dimers. Their 2- and 4-isomeric, homo-
and heterodimeric structures were identified using a combination of HPLC-ESI-(+)-HR-MS/MS spectrometry
and high-resolution dqf-COSY NMR spectroscopy. Structure assignments were confirmed by total synthesis
of representative examples. Functional characterization using holding assays indicated that males of
Caenorhabditis remanei and Caenorhabditis nigoni are exclusively retained by their conspecific ascaroside
dimers, demonstrating that dimerization of conserved monomeric building blocks represents a yet unde-
scribed mechanism that generates species-specific signaling molecules in the Caenorhabditis genus. Comparative ascaroside profiling of Caenorhabditis nematodes using HPLC-ESI-(-)-MS/MS precursor ion
scanning revealed a class of highly species-specific ascaroside dimers. Their 2- and 4-isomeric, homo-
and heterodimeric structures were identified using a combination of HPLC-ESI-(+)-HR-MS/MS spectrometry
and high-resolution dqf-COSY NMR spectroscopy. Structure assignments were confirmed by total synthesis
of representative examples. Functional characterization using holding assays indicated that males of
Caenorhabditis remanei and Caenorhabditis nigoni are exclusively retained by their conspecific ascaroside
dimers, demonstrating that dimerization of conserved monomeric building blocks represents a yet unde-
scribed mechanism that generates species-specific signaling molecules in the Caenorhabditis genus. Comparative ascaroside profiling of Caenorhabditis nematodes using HPLC-ESI-(-)-MS/MS precursor ion
scanning revealed a class of highly species-specific ascaroside dimers. Their 2- and 4-isomeric, homo-
and heterodimeric structures were identified using a combination of HPLC-ESI-(+)-HR-MS/MS spectrometry
and high-resolution dqf-COSY NMR spectroscopy. Structure assignments were confirmed by total synthesis
of representative examples. Functional characterization using holding assays indicated that males of
Caenorhabditis remanei and Caenorhabditis nigoni are exclusively retained by their conspecific ascaroside
dimers, demonstrating that dimerization of conserved monomeric building blocks represents a yet unde-
scribed mechanism that generates species-specific signaling molecules in the Caenorhabditis genus. Comparative ascaroside profiling of Caenorhabditis nematodes using HPLC-ESI-(-)-MS/MS precursor ion
scanning revealed a class of highly species-specific ascaroside dimers. Their 2- and 4-isomeric, homo-
and heterodimeric structures were identified using a combination of HPLC-ESI-(+)-HR-MS/MS spectrometry
and high-resolution dqf-COSY NMR spectroscopy. Structure assignments were confirmed by total synthesis
of representative examples. Functional characterization using holding assays indicated that males of
Caenorhabditis remanei and Caenorhabditis nigoni are exclusively retained by their conspecific ascaroside
dimers, demonstrating that dimerization of conserved monomeric building blocks represents a yet unde-
scribed mechanism that generates species-specific signaling molecules in the Caenorhabditis genus. Comparative ascaroside profiling of Caenorhabditis nematodes using HPLC-ESI-(-)-MS/MS precursor ion
scanning revealed a class of highly species-specific ascaroside dimers. Their 2- and 4-isomeric, homo-
and heterodimeric structures were identified using a combination of HPLC-ESI-(+)-HR-MS/MS spectrometry
and high-resolution dqf-COSY NMR spectroscopy. Structure assignments were confirmed by total synthesis
of representative examples. Functional characterization using holding assays indicated that males of
Caenorhabditis remanei and Caenorhabditis nigoni are exclusively retained by their conspecific ascaroside
dimers, demonstrating that dimerization of conserved monomeric building blocks represents a yet unde-
scribed mechanism that generates species-specific signaling molecules in the Caenorhabditis genus. Comparative ascaroside profiling of Caenorhabditis nematodes using HPLC-ESI-(-)-MS/MS precursor ion
scanning revealed a class of highly species-specific ascaroside dimers. Their 2- and 4-isomeric, homo-
and heterodimeric structures were identified using a combination of HPLC-ESI-(+)-HR-MS/MS spectrometry
and high-resolution dqf-COSY NMR spectroscopy. Structure assignments were confirmed by total synthesis
of representative examples. Functional characterization using holding assays indicated that males of
Caenorhabditis remanei and Caenorhabditis nigoni are exclusively retained by their conspecific ascaroside
dimers, demonstrating that dimerization of conserved monomeric building blocks represents a yet unde-
scribed mechanism that generates species-specific signaling molecules in the Caenorhabditis genus. Comparative ascaroside profiling of Caenorhabditis nematodes using HPLC-ESI-(-)-MS/MS precursor ion
scanning revealed a class of highly species-specific ascaroside dimers. Their 2- and 4-isomeric, homo-
and heterodimeric structures were identified using a combination of HPLC-ESI-(+)-HR-MS/MS spectrometry
and high-resolution dqf-COSY NMR spectroscopy. Structure assignments were confirmed by total synthesis
of representative examples. Functional characterization using holding assays indicated that males of
Caenorhabditis remanei and Caenorhabditis nigoni are exclusively retained by their conspecific ascaroside
dimers, demonstrating that dimerization of conserved monomeric building blocks represents a yet unde-
scribed mechanism that generates species-specific signaling molecules in the Caenorhabditis genus.
\end{abstract}

\section{Introduction}

Chemical communication in nematodes is mediated by ascarosides, glycolipids of the 3,6-dideoxy-arabino-aldohexose L-ascarylose linked to a wide range of homologous aglycones derived from the peroxisomal $\beta$-oxidation cycle (Fig. 1). ${ }^{1-8}$

Ascaroside signalling is widely conserved in nematodes ${ }^{9}$ and modulates a large diversity of biological functions. ${ }^{7,8}$ Over the past decade the development of sensitive ascaroside-selective screens based on characteristic fragment ions observed during electrospray ionization-tandem mass spectrometry

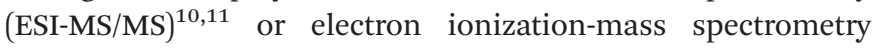
$(\text { EI-MS })^{12}$ along with comparative analysis of wild-type and peroxisomal $\beta$-oxidation mutant metabolomes ${ }^{13-15}$ has facilitated the identification of several hundreds of ascaroside structures, most of which have not yet been characterized with respect to their potential biological functions. Systematic bioassays with

${ }^{a}$ Department of Bioorganic Chemistry, Max Planck Institute for Chemical Ecology, Hans-Knöll Straße 8, D-07745 Jena, Germany

${ }^{b}$ Laboratory for Bioanalytical Chemistry, Institute of Chemistry, University of

Neuchâtel, Avenue de Bellevaux 51, CH-2000 Neuchâtel, Switzerland.

E-mail: stephan.vonreuss@unine.ch

${ }^{c}$ Research Group Biosynthesis/NMR, Max Planck Institute for Chemical Ecology,

Hans-Knöll Straße 8, D-07745 Jena, Germany

$\dagger$ Electronic supplementary information (ESI) available: Figures as indicated in the main text, NMR spectra of isolated and synthetic compounds. See DOI: 10.1039/d0ob00799d

$\$$ These authors contributed equally.

$\S$ Present Address: Department of Integrative Evolutionary Biology, Max Planck Institute for Developmental Biology, Max-Planck-Ring 9, D-72076 Tübingen, Germany. ascarosides, while limited in number and scope, established that even minor changes in molecular structure dramatically impact their biological activities, ${ }^{16}$ which demonstrates that ascaroside signalling represents a complex "chemical language". Comparative analysis of several closely related Caenorhabditis species revealed that most simple ascarosides are highly conserved. Short chain ascarosides carrying ( $\omega-1)$ linked odd numbered C5, C7, C9, and C11 acyl chains as aglycones (1) are particularly abundant and widely distributed. ${ }^{17}$ These common ascarosides serve as scaffolds for speciesspecific modifications including the hydroxylation of the aglycone ${ }^{17,18}$ and epimerization of the L-ascarylose unit (e.g. 2), ${ }^{19}$ as well as the attachment of additional building

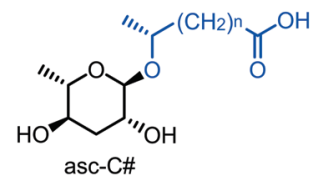<smiles>C[C@@H](O)[C@H](O)CCC/C=C/C(=O)O</smiles>

(1)<smiles>C[C@@H](CCC(=O)O)O[C@@H]1O[C@H](C)[C@H](OC(=O)c2c[nH]c3ccccc23)C[C@H](O)[C@@H]1C(C)(C)C</smiles><smiles>CCCC(CCC1C[C@H]1CC(=O)O)OC(=O)C[C@H](C)O[C@@H]1O[C@H](C)[C@@H](O)C[C@H]1O</smiles>

Fig. 1 General structure of common ascarosides (1) along with species-specific derivatives from C. nigoni (2 and 3 ) and C. remanei (4); L-ascarylose unit in black, aglycone moiety in blue, and species-specific modifications in red. 
blocks from diverse primary metabolic pathways to generate complex modular libraries (e.g. 3) ${ }^{13,15,20-22}$ Here we show that homo- and heterodimerization of conserved ascaroside building blocks represents another mechanism that creates speciesspecific signalling molecules in the Caenorhabditis.

\section{Results and discussion}

Comparative ascaroside profiling reveals species-specific dimers

Comparative ascaroside profiling of the nematode culture supernatants (the exometabolomes) of Caenorhabditis nigoni and Caenorhabditis remanei (Fig. 2) using HPLC-ESI-(-)-MS/MS precursor ion scanning for the highly characteristic fragment ion at $\mathrm{m} / \mathrm{z} 73.0\left[\mathrm{C}_{3} \mathrm{H}_{5} \mathrm{O}_{2}\right]^{10}$ revealed a diversity of common simple ascarosides with $(\omega-1)$-linked side chains ranging from C4 to $\mathrm{C} 11(\mathbf{1}, n=1-8)$. In addition, some species-specific derivatives could be identified, including hydroxyacyl ascarosides ${ }^{17}$ and the corresponding 4-epimeric caenorhabdoside cae-7OH- $\Delta$ C9 (2) ${ }^{19}$ as well as indole ascarosides dominated by

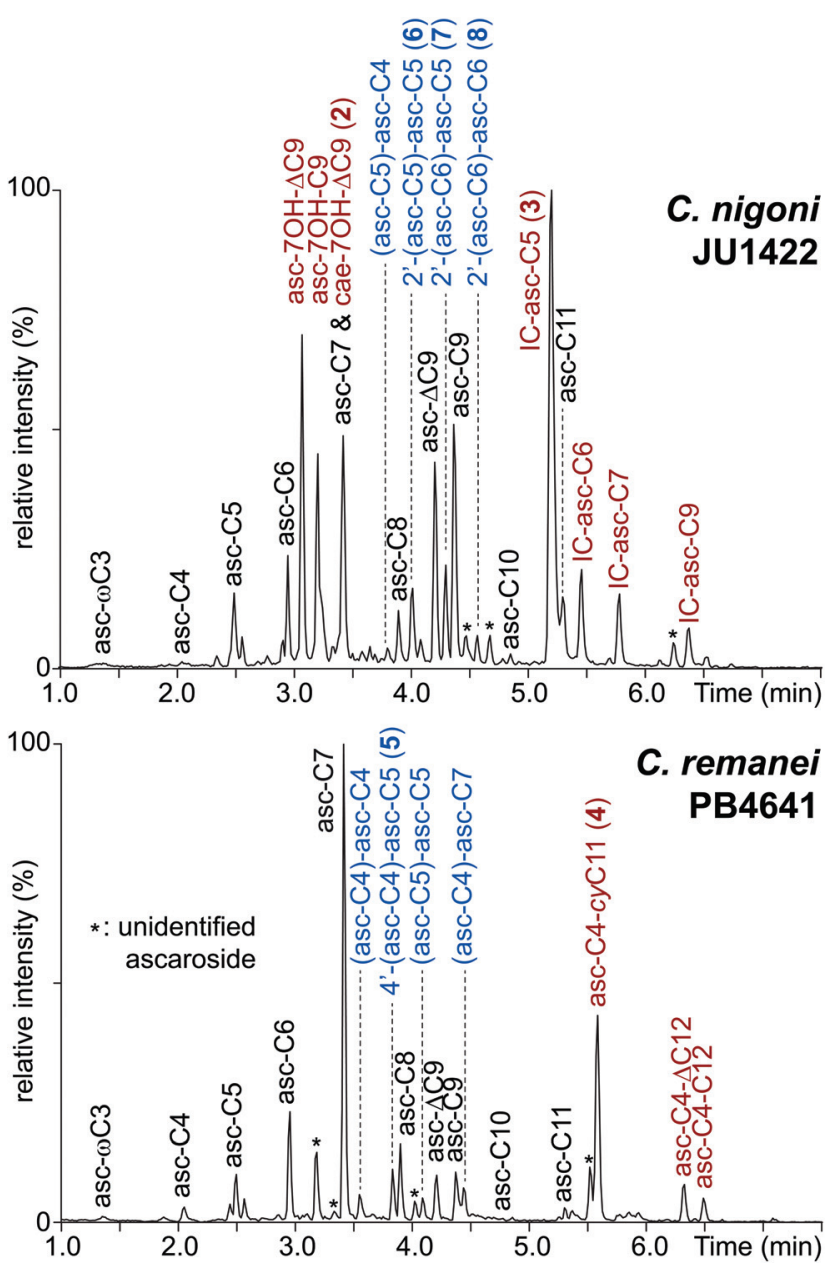

Fig. 2 Ascaroside profiling in C. nigoni and C. remanei by MS/MS precursor ion scanning for $\mathrm{m} / \mathrm{z} 73.0\left[\mathrm{C}_{3} \mathrm{H}_{5} \mathrm{O}_{2}\right]$ reveals common ascarosides (black) along with species-specific components (red) including homoand heterodimers (blue).
IC-asc-C5 $(3)^{23}$ from $C$. nigoni or the fatty acid ascarosides dominated by asc-C4-cyC11 (4) from C. remanei. ${ }^{24}$

A yet uncharacterized class of putative ascarosides was observed in small quantities in both $C$. nigoni and C. remanei (Fig. 2) as well as other Caenorhabditis species. Their universal molecular formula $\mathrm{C}_{(20+n)} \mathrm{H}_{(34+2 n)} \mathrm{O}_{11}(n=0-10)$ was determined by high resolution mass spectrometry (HR-MS), which suggested a homologous series of ascaroside dimers (Table S1 $\dagger$ ). Systematic analysis of the ESI-(-)-HR-MS/MS spectra (Fig. 3) revealed neutral loss of an ascarylose unit [M $\mathrm{C}_{6} \mathrm{H}_{13} \mathrm{O}_{4}$ ] to form ion $\mathbf{I}$ along with a monomeric ascaroside building block II from cleavage of the ester linkage, thus, facilitating the differentiation of isomeric homo and heterodimers. ESI-(+)-HR-MS/MS results in an oxonium ion III corresponding to the esterified ascaroside building block, as well as the loss of the terminal aglycone to yield fragment ion IV composed of both ascarylose units connected by their aglycone linker, which ultimately facilitates the assignment of both monomeric building blocks along with their order of attachment.

Comparative profiling of fourteen Caenorhabditis species demonstrated a high degree of species-specificity. Eight out of
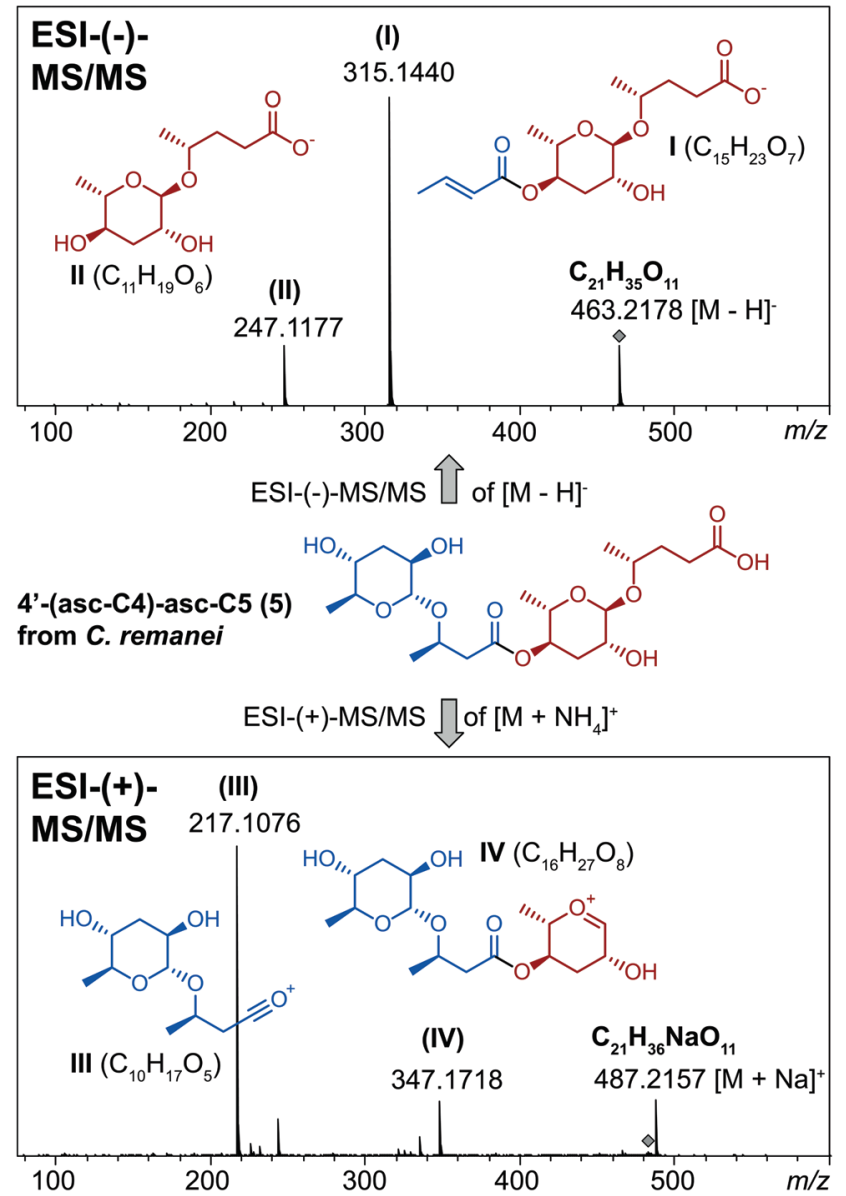

Fig. 3 ESI-MS/MS analysis facilitates structure assignment of dimeric ascarosides as shown for 4'-(asc-C4)-asc-C5 (5) from C. remanei (monomeric units in red and blue). 
fourteen species were found to be devoid of dimeric ascarosides, which are abundant in members of the Elegans group but could not be detected in the model organism C. elegans (Fig. S1†). Monomeric building blocks and their order of assembly were identified by HPLC-ESI-(+)-MS/MS (Fig. S2 $\dagger$ ), which resulted in the characterization of 32 dimeric ascarosides (Table $\mathrm{S} 1 \dagger$ ). The dominating ascaroside dimers were identified as 4'-(asc-C4)-asc-C5 (5) in C. remanei, 2'-(asc-C6)asc-C5 (7) in C. nigoni, (asc-C4)-asc-C4 in C. brenneri, (asc-C5)asc-C5 in C. tropicalis, (asc-C6)-asc-C6 in C. sinica, and (ascC7)-asc-C9 in C. briggsae, (Fig. S3†). Considering that the monomeric building blocks with sidechains ranging from $\mathrm{C} 4$ to $\mathrm{C} 11$ are conserved in Caenorhabditis spp. ${ }^{17}$ this specificspecificity demonstrates that the biogenesis of ascaroside dimers is tightly controlled. Dimeric ascarosides carrying unsaturated side chains (such as (asc- $\Delta$ C9)-asc-C7) were also detected (Table $\mathrm{S} 1 \dagger$ ). Furthermore, traces of three ascaroside trimers in C. nigoni were identified as ((asc-C6)-asc-C6)-asc-C $x$ $(x=4,5$, and 6) (Fig. S4, Table S4†).

Structure assignments were confirmed by isolation of representative components (Fig. 4) from crude Caenorhabditis exometabolome extracts by solid phase extraction (SPE) and semipreparative HPLC on RP-C18. Fractionation of $1.5 \mathrm{~L}$ of the C. remanei liquid culture supernatant afforded approximately $130 \mu \mathrm{g}$ of the 4-linked 4'-(asc-C4)-asc-C5 (5) (Fig. S5†). Inspection of high resolution $d q f$-COSY spectra indicated that the characteristic 4-linkage of $\mathbf{5}$ (that could not be derived from the MS/MS data) could already be deduced in the partially purified metabolome mixture obtained after the 1st SPE fractionation step (Fig. S6†), which was utilized for the structure assignment of additional ascaroside dimers. Combined SPE and HPLC fractionation of $1.6 \mathrm{~L}$ of the $C$. nigoni liquid culture supernatant gave mixtures enriched in 2-linked 2 '-(ascC5)-asc-C5 (6), 2'-(asc-C6)-asc-C5 (7), and 2'-(asc-C6)-asc-C6 (8) (Fig. $\mathrm{S} 7 \dagger$ ) that were identified using a combination of ESI(+)-HR-MS/MS (Fig. S8†) and $d q f$-COSY techniques (Fig. S9, Table S2†), demonstrating that their species-specific biosyn-
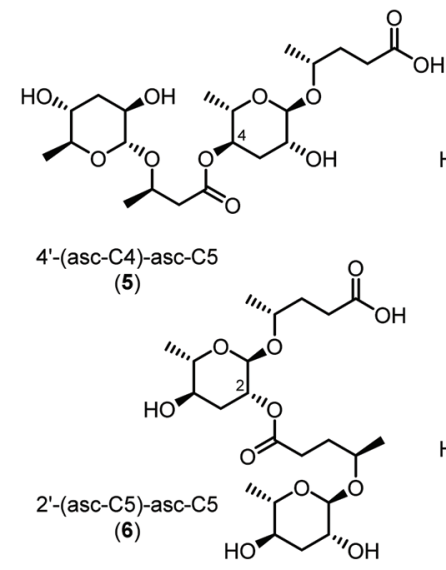

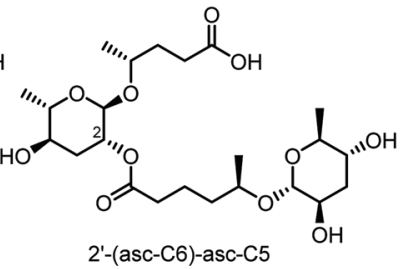

(7)

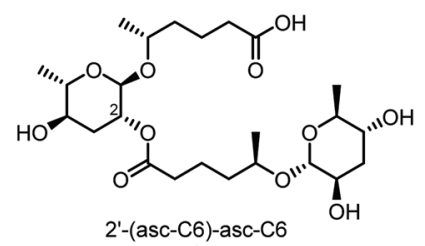

(8)
Fig. 4 Ascaroside dimers isolated from Caenorhabditis remanei PB4641 (5) and Caenorhabditis nigoni JU1422 (6-8). thesis in the Caenorhabditis spp. includes the formation of homo- and heterodimeric 2- and 4-isomers (Fig. 4).

\section{Total synthesis of ascaroside dimers}

In order to unambiguously establish their structure assignments and to obtain pure materials for the characterization of biological activities, 2- and 4-isomeric pairs of homodimeric 2'/4'-(asc-C6)-asc-C6 and heterodimeric 2'/4'-(asc-C6)-asc-C5 were synthesized as shown in Fig. 5. Glycosylation of homologous $(R)$-2-hydroxyalkenes with 2,4-di-O-benzoyl-ascarylose (9, prepared in 8 steps from commercially available $\mathrm{L}^{-}$ (+)-rhamnose $)^{25,26}$ was accomplished using the trichloroacetimidate route $^{27}$ to afford the $(\omega-1)$-linked terminal alkenyl ascarosides $(\mathbf{1 0 a} / \mathbf{b})$. After alkaline hydrolysis, cross metathesis with benzyl acrylate catalysed by Grubbs 2 nd generation catalyst $^{28}$ furnished the $\alpha, \beta$-unsaturated benzyl esters $11 \mathbf{a} / \mathbf{b}$ that served as monomeric building blocks for the synthesis of ascaroside dimers. Furthermore, one part of the hexenoate homolog 11b was derivatized with tert-butyldimethylsilyl chloride and $O$-debenzylated by palladium catalysed hydrogenation to yield the second monomeric building block 12. Coupling of the homologous ascaroside benzyl esters (11a or 11b) with the 2,4-di-O-TBS protected ascaroside (12) by Steglich esterification $^{29}$ afforded mixtures of the trimeric 2,4-diester and both dimeric monoesters. Using an optimized 2:1 ratio of the monomeric building blocks 11 and 12 afforded predominantly the 2- and 4-isomeric dimers that were separated by column chromatography on silica gel. Next, palladium catalysed hydrogenation furnished the free acids that were finally deprotected using hydrogen fluoride in pyridine to give the 2 -isomeric ( 7 and $\mathbf{8}$ ) and 4-isomeric (13a/b) ascaroside dimers that were iso-
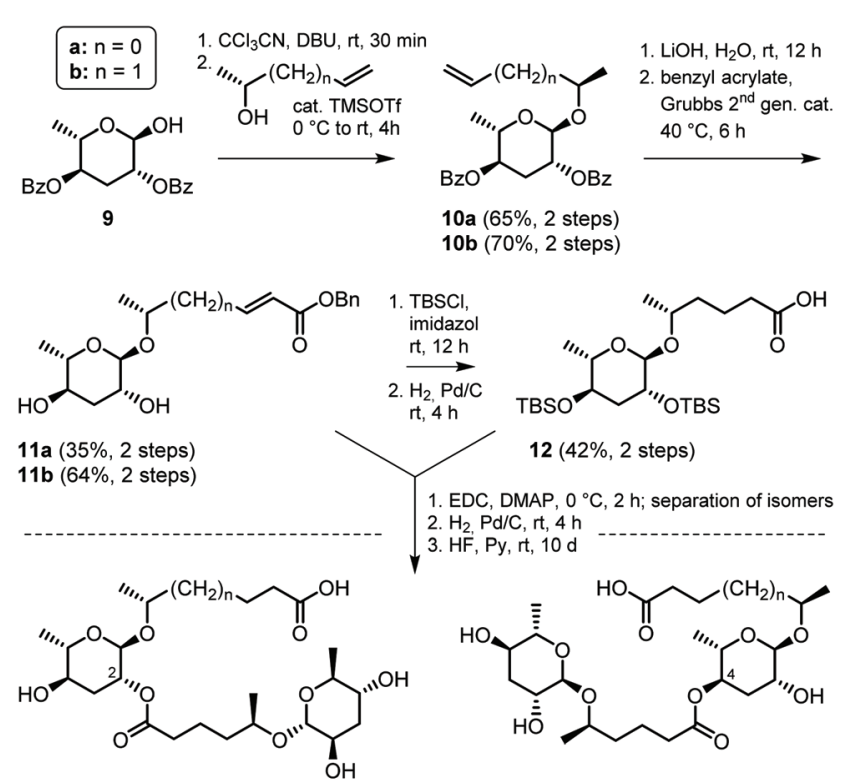

2 -(asc-C6)-asc-C5 $(7, \mathrm{n}=0)(8 \%, 3$ steps) $\quad 4$ '-(asc-C6)-asc-C5 (13a) $(15 \%, 3$ steps) $2 '$-(asc-C6)-asc-C6 $(8, n=1)(11 \%, 3$ steps) $\quad 4$ '-(asc-C6)-asc-C6 (13b) (4\%, 3 steps)

Fig. 5 Total synthesis of homo- and hetero-dimeric ascarosides from C. nigoni. 
lated by RP-C18-SPE. Comparative NMR and HPLC-MS analysis confirmed that synthetic 2'-(asc-C6)-asc-C5 (7) and 2'-(asc-C6)asc-C6 (8) are identical to the natural products isolated from C. nigoni (Fig. S10 and S11†).

\section{Functional characterization of ascaroside dimers}

Potential behavioural activities were characterized using a holding assay that quantifies nematode retention in ascaroside conditioned scoring regions in comparison to solvent control (Fig. 6). Females of C. remanei and C. nigoni did not respond to any of the dimeric ascarosides tested. $C$. remanei males were retained by $100 \mathrm{fmol}$ of the conspecific 4 '-(asc-C4)-asc-C5 (5), but not by the hetero-specific 2'-(asc-C6)-asc-C5 (7) and 2'-(ascC6)-asc-C6 (8). In contrast C. nigoni males were retained by 100 fmol of the conspecific 2'-(asc-C6)-asc-C5 (7) and 2'-(asc-C6)-
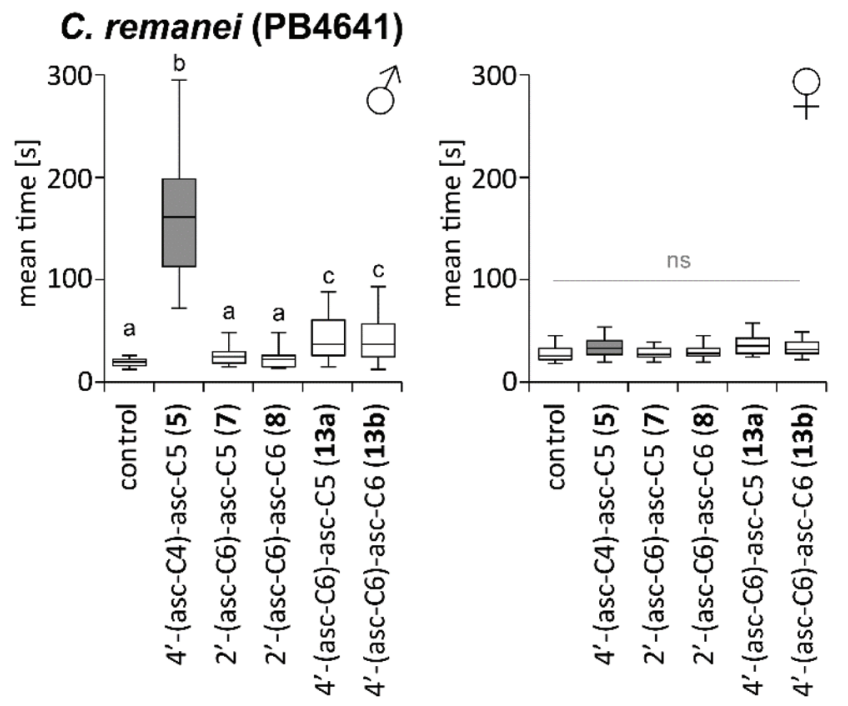

\section{C. nigoni (JU1422)}
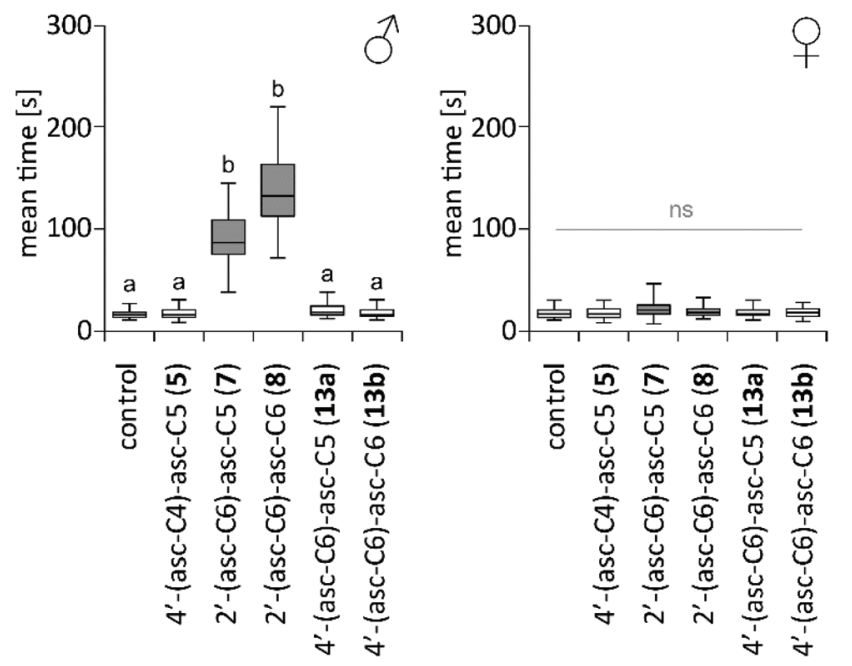

Fig. 6 Species-specific retention of $C$. remanei and $C$. nigoni in response to $100 \mathrm{fmol}$ of the ascaroside dimers shows male-specific retention to conspecific components (different letters indicate statistically significant differences between groups, $P<0.01$, ANOVA with Dunett's post hoc test, $n=20$, values represent means \pm 1 SD).
asc-C6 (8) but not by any of the hetero-specific 4-linked components such as 4'-(asc-C4)-asc-C5 (5), 4'-(asc-C6)-asc-C5 (13a), and 4'-(asc-C6)-asc-C6 (13b), demonstrating that males of both species are exclusively retained by their own conspecific ascaroside dimers.

\section{Conclusions}

In conclusion, combination of HR-MS/MS and NMR techniques along with total synthesis facilitated the identification of 2- and 4-isomeric homologous series of ascaroside dimers in Caenorhabditis spp. The homodimeric 4'-(asc-C7)-asc-C7 (SMID: dasc $\# 1)^{30}$ has previously been shown to act as a modulator of mouth form dimorphism in the androdioecious nematode Pristionchus pacificus, diplogastridae, which also produces a variety of 2-linked ascaroside dimers that carry an additional 4-linked ureido-isobutyrate moiety. ${ }^{31,32}$ Among the gonochoristic $C$. remanei and $C$. nigoni the males are exclusively retained by ecologically significant amounts of their conspecific ascaroside dimers, demonstrating that dimerization represents an effective mechanism to generate species-specific signalling molecules. Considering just the most prevalent monomeric ascaroside building blocks with ( $\omega$-1)-linked acyl aglycones ranging from 4 to 11 carbons, their dimerization via the 2 - or 4-position results in 128 theoretically possible structures of which 27 were now characterized in Caenorhabditis species using HR-MS/MS techniques. Incorporation of unsaturated aglycones as well as the assembly of ascaroside trimers further expands the structural diversity of these components. Remarkably, dimers carrying even numbered aglycones were particularly prevalent, although the corresponding monomeric building blocks such as asc-C4 $(\mathbf{1}, n=1)$ and asc-C6 $(\mathbf{1}, n=3)$ are rare and cannot be produced by canonical $\beta$-oxidation of the predominating homologous series of odd numbered ascarosides. Along with the hydroxylation of the ascaroside aglycones, epimerization of the ascarylose unit, and attachment of additional building blocks from primary metabolic pathways, the dimerization of monomeric units represents a highly effective mechanism to generate species-specific ascarosides, which form a complex chemical language in nematode communication.

\section{Experimental}

\section{Organisms}

Wild-type Caenorhabditis isolates of C. afra JU1286 (Ghana), C. brenneri PB2801 (Costa Rica), C. briggsae AF16 (India), C. doughertyi JU1771 (India), C. elegans N2 (UK), C. japonica DF5081 (Japan), C. monodelphis JU1667 (Germany), C. nigoni JU1422 (India), C. portoensis EG4788 (Portugal), C. remanei PB4641 (United States), C. sinica JU727 (China), C. tropicalis JU1373 (La Réunion), C. virilis JU1968 (France), and C. wallacei JU1904 (Indonesia), as well as Escherichia coli OP50 (uracil aux- 
otroph) were obtained from the Caenorhabditis elegans Genetics Center (CGC).

\section{Preparation of exometabolome extracts}

Fourteen wild-type Caenorhabditis species were cultivated at $23{ }^{\circ} \mathrm{C}$ on Nematode Growth Medium (NGM) $\operatorname{agar}^{33}$ seeded with $E$. coli OP50. Mixed stage nematodes from five $10 \mathrm{~cm}$ plates were collected in M9 phosphate buffer ${ }^{33}$ to serve as inoculums for liquid cultures grown in $100 \mathrm{ml} \mathrm{S}$-medium $^{33}$ at $23^{\circ} \mathrm{C}$ and $150 \mathrm{rpm}$. Concentrated $E$. coli OP50 bacteria pellet (from an overnight culture in lysogeny broth (LB) medium at $37^{\circ} \mathrm{C}$ and $170 \mathrm{rpm}$ and collected by centrifugation at $5000 \mathrm{~g}$ for $10 \mathrm{~min}$ ) was provided as food from day 1 to day 7 , after which the cultures were starved for 7 days. After 14 days, nematodes were separated by centrifugation ( $5 \mathrm{~min}$ at $5000 \mathrm{~g}$ ). The filtered supernatant representing the exometabolome was frozen at $-80{ }^{\circ} \mathrm{C}$, lyophilized, and extracted with $3 \times 100 \mathrm{ml}$ methanol for $12 \mathrm{~h}$ each. The combined extract was filtered, concentrated to dryness at $40{ }^{\circ} \mathrm{C}$ under reduced pressure, reconstituted in $1 \mathrm{ml}$ methanol, and aliquots were analysed by HPLC-HR-MS/ MS in positive and negative mode, as well as HPLC-ESI-(-)-MS/ MS precursor ion scanning for $m / z 73.0\left[\mathrm{C}_{3} \mathrm{H}_{5} \mathrm{O}_{2}\right]$.

\section{Liquid chromatography-electrospray ionization-high resolution-tandem mass spectrometry (HPLC-ESI-HR-MS/MS)}

HPLC-ESI-HRMS analysis of crude nematode exometabolome extracts and exometabolome fractions was performed using a Dionex UltiMate 3000 HPLC instrument coupled to a Bruker Maxis ultrahigh resolution (UHR) qTOF mass spectrometer equipped with an electrospray ionization (ESI) unit operated in positive or negative mode. Chromatographic separations were achieved using an Agilent ZORBAX Eclipse XDB-C18 column $(250 \times 3 \mathrm{~mm}, 5 \mu \mathrm{m}$ particle diameter) with a flow rate of $400 \mu \mathrm{l}$ $\mathrm{min}^{-1}$ and gradient elution starting at 3\% acetonitrile in $0.5 \%$ aqueous acetic acid (v/v) for 5 minutes followed by a linear increase to $100 \%$ acetonitrile with $0.5 \%$ acetic acid (v/v) within 35 minutes. Data were analysed with the Compass DataAnalysis 4.3 software (Bruker).

\section{Liquid chromatography electrospray ionization precursor ion scanning (HPLC-ESI-MS/MS)}

MS/MS precursor ion scanning for $m / z 73.0\left[\mathrm{C}_{3} \mathrm{H}_{5} \mathrm{O}_{2}\right]$ was performed using an Agilent 1260 HPLC instrument (Agilent Technologies) coupled to an API5000 Triple Quadrupole mass spectrometer (AB Sciex, Darmstadt) equipped with an electrospray ionization (ESI) unit operated in negative mode. A collision energy of -34 was applied. Chromatographic separations were achieved using an Agilent ZORBAX Eclipse XDB-C18 column $(50 \times 4.6 \mathrm{~mm}, 1.8 \mu \mathrm{m}$ particle diameter) (Agilent Technologies) with a flow rate of $1.1 \mathrm{ml} \mathrm{min}^{-1}$ and gradient elution starting at $5 \%$ acetonitrile in $0.05 \%$ aqueous formic acid $(\mathrm{v} / \mathrm{v})$ followed by a linear in-crease to $95 \%$ acetonitrile with $0.05 \%$ formic acid (v/v) within 10 minutes. Data were analysed with the Analyst 1.6 software (AB Sciex).

\section{NMR spectroscopy}

NMR spectra were recorded in $\mathrm{CD}_{3} \mathrm{OD}$ at $400 \mathrm{MHz}$ for ${ }^{1} \mathrm{H}$ and $100 \mathrm{MHz}$ for ${ }^{13} \mathrm{C}$ using a Bruker Avance III HD 400 instrument equipped with a $5 \mathrm{~mm}$ BBFO probe (MPICE), Bruker Avance II 400 instrument equipped with a $5 \mathrm{~mm}$ BBFO probe (NPAC, UniNE), or at $700 \mathrm{MHz}$ for ${ }^{1} \mathrm{H}$ and $175 \mathrm{MHz}$ for ${ }^{13} \mathrm{C}$ using a Bruker Avance III HD 700 instrument equipped with a $1.7 \mathrm{~mm}$ TCI microcryoprobe (MPICE). Residual solvent signals with ${ }^{1} \mathrm{H}$ at $3.31 \mathrm{ppm}$ and ${ }^{13} \mathrm{C}$ at $49.05 \mathrm{ppm}$ were used as internal standard. Two-dimensional homonuclear double quantum filtered $(d q f)$-COSY spectra were recorded using phase cycling for coherence selection. For the isolated compounds a total of 32 scans were acquired using a time domain of 8k in F2 (acquisition time of $1.2 \mathrm{~s}$ ) and 512 increments in F1. Spectra were zero-filled prior to Fourier transformation, phased, and baseline corrected using the Topspin 3.2 (Bruker) and MNova 9.0 (Mestrelab Research) software.

\section{Enrichment of dimeric ascarosides from Caenorhabditis exometabolome extracts}

Dimeric ascarosides were enriched from exometabolome extracts obtained from 1.6 L of a Caenorhabditis nigoni JU1422 liquid culture supernatant ${ }^{17}$ and $1.5 \mathrm{~L}$ of a Caenorhabditis remanei PB4641 liquid culture supernatant ${ }^{24}$ obtained as previously described. The filtered supernatant was frozen at $-80{ }^{\circ} \mathrm{C}$, lyophilized, and the residue extracted with $3 \times 100 \mathrm{ml}$ methanol for $12 \mathrm{~h}$ each. The filtered extracts were concentrated to dryness under reduced pressure and the resulting exometabolome extract were adsorbed onto $2 \mathrm{~g}$ of Celite and fractionated by solid phase extraction (SPE) on $5 \mathrm{~g}$ reverse phase C18 cartridges (Chromabond, Macherey-Nagel) using a stepwise gradient of methanol in water as eluent ( 0 to $100 \%$ in $10 \%$ steps, v/v) to afford 10 fractions (20 ml each). Fractions were concentrated to dryness under reduced pressure and analyzed by HPLC-ESI-HR-MS/MS. Fraction eluting with 40-70\% methanol that were found to be rich in dimeric ascarosides were either fractionated again by solid phase extraction (SPE) on $1 \mathrm{~g}$ reverse phase C18-endcapped cartridges (Chromabond, Macherey-Nagel) using a stepwise gradient of methanol in water as eluent ( 0 to $100 \%$ in $10 \%$ steps, v/v) to afford 10 fractions ( $5 \mathrm{ml}$ each) and/or fractions containing the target components according to HPLC-ESI-(-)-HR-MS were subsequently submitted to semi-preparative HPLC using an Agilent HP-1100 HPLC instrument equipped with a Grom-Sil 120 ODS-4 HE column $(250 \times 8 \mathrm{~mm}, 5 \mu \mathrm{m})$ coupled to a Gilson 206 Abimed

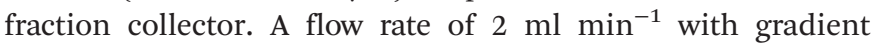
elution was used starting at $3 \%$ acetonitrile in $0.5 \%$ aqueous acetic acid (v/v) for 3 minutes, followed by a linear increase to $100 \%$ acetonitrile with $0.5 \%$ acetic acid (v/v) within 30 minutes. Aliquots of $10 \mu \mathrm{l}$ were analysed by HPLC-ESI(-)-HR-MS as described before. Fractions containing the target compounds were concentrated to dryness under reduced pressure, dried in high vacuum, and the residues were dissolved in $550 \mu \mathrm{CD}_{3} \mathrm{OD}$ and analysed by one- and two-dimensional NMR spectroscopy. 
(4R)-4-[[3,6-Dideoxy-4-O-[(3R)-3-[(3,6-dideoxy- $\alpha$-L-arabino-hexopyranosyl)oxy]-1-oxo-butyl]- $\alpha$-L-arabino-hexopyranosyl] oxy]-pentanoic acid (4'-(asc-C4)-asc-C5, 5) isolated from the C. remanei PB4641 exometabolome (approximately $130 \mu \mathrm{g}$ ); ${ }^{1} \mathrm{H} \quad \mathrm{NMR}$ $\left(700 \mathrm{MHz}, \mathrm{CD}_{3} \mathrm{OD}\right) \delta 1.15(3 \mathrm{H}, \mathrm{d}, J=6.1 \mathrm{~Hz}), 1.16(3 \mathrm{H}, \mathrm{d}, J=6.1$ $\mathrm{Hz}), 1.21(3 \mathrm{H}, \mathrm{d}, J=6.2 \mathrm{~Hz}), 1.22(3 \mathrm{H}, \mathrm{d}, J=6.2 \mathrm{~Hz}), 1.72$ (ddd, $J=13.0 \mathrm{~Hz}, J=11.7 \mathrm{~Hz}, J=3.7 \mathrm{~Hz}), 1.83(2 \mathrm{H}, \mathrm{m}), 1.92(1 \mathrm{H}, \mathrm{dt}, J=$ $13.3 \mathrm{~Hz}, J=3.9 \mathrm{~Hz}), 1.92(1 \mathrm{H}, \mathrm{ddd}, J=13.2 \mathrm{~Hz}, J=11.4 \mathrm{~Hz}, J=$ $3.8 \mathrm{~Hz}), 2.07(1 \mathrm{H}, \mathrm{dt}, J=12.6 \mathrm{~Hz}, J=3.8 \mathrm{~Hz}), 2.22(1 \mathrm{H}, \mathrm{ddd}, J=$ $14.9 \mathrm{~Hz}, J=9.8 \mathrm{~Hz}, J=6.1 \mathrm{~Hz}), 2.35(1 \mathrm{H}, \mathrm{ddd}, J=15.1 \mathrm{~Hz}, J=$ $10.0 \mathrm{~Hz}, J=6.4 \mathrm{~Hz}), 2.50(1 \mathrm{H}, \mathrm{dd}, J=15.1 \mathrm{~Hz}, J=5.4 \mathrm{~Hz}), 2.56$ $(1 \mathrm{H}, \mathrm{dd}, J=15.0 \mathrm{~Hz}, J=7.5 \mathrm{~Hz}), 3.51(1 \mathrm{H}, \mathrm{ddd}, J=11.6 \mathrm{~Hz}, J=$ $9.5 \mathrm{~Hz}, J=4.8 \mathrm{~Hz}), 3.62(1 \mathrm{H}, \mathrm{dq}, J=9.6 \mathrm{~Hz}, J=6.2 \mathrm{~Hz}), 3.70(1 \mathrm{H}$, s.br), $3.72(1 \mathrm{H}, \mathrm{s.br}), 3.82(1 \mathrm{H}, \mathrm{m}), 3.90(1 \mathrm{H}, \mathrm{dq}, J=9.6 \mathrm{~Hz}, J=$ $6.1 \mathrm{~Hz}), 4.23(1 \mathrm{H}, \mathrm{m}), 4.67(1 \mathrm{H}, \mathrm{s}), 4.69(1 \mathrm{H}, \mathrm{s}), 4.87(1 \mathrm{H}, \mathrm{ddd}, J=$ $11.3 \mathrm{~Hz}, J=9.6 \mathrm{~Hz}, J=6.1 \mathrm{~Hz}) ;{ }^{13} \mathrm{C}$ NMR $\left(175 \mathrm{MHz}, \mathrm{CD}_{3} \mathrm{OD}\right) \delta$ 18.0, 18.0, 18.7, 18.7, 32.7, 35.0, 35.2, 35.6, 43.1, 67.8, 67.9, 69.0, 69.2, 69.3, 71.0, 71.4, 72.2, 96.8, 97.1, 171.8, 182.1 (Table S2†); ESI-(-)-HR-MS: obs. $m / z 463.2176[\mathrm{M}-\mathrm{H}]^{-}$, calc. $m / z 463.2185$ for $\mathrm{C}_{21} \mathrm{H}_{35} \mathrm{O}_{11}$ (Table $\mathrm{S} 1 \dagger$ ).

$(4 R)-4-[[3,6-D i d e o x y-2-O-[(4 R)-4-[(3,6-d i d e o x y-\alpha-$-L-arabino-hexopyranosyl)oxy]-1-oxo-pentyl]- $\alpha$-L-arabino-hexopyranosyl]oxy]-pentanoic acid (2'-(asc-C5)-asc-C5, 6) enriched from the C. nigoni JU1422 exometabolome (approximately $50 \mu \mathrm{g}$ ) along with dominating asc-C8; ${ }^{1} \mathrm{H}$ NMR $\left(400 \mathrm{MHz}, \mathrm{CD}_{3} \mathrm{OD}\right) \delta 1.14(3 \mathrm{H}, \mathrm{d}, J=$ $6.1 \mathrm{~Hz}), 1.14(3 \mathrm{H}, \mathrm{d}, 6.3 \mathrm{~Hz}), 1.22(3 \mathrm{H}, \mathrm{d}, J=6.2 \mathrm{~Hz}), 1.23(3 \mathrm{H}, \mathrm{d}$, $J=6.2 \mathrm{~Hz}), 1.77(1 \mathrm{H}, \mathrm{m}), 1.80(4 \mathrm{H}, \mathrm{m}), 1.87(1 \mathrm{H}, \mathrm{ddd}, J=13.2 \mathrm{~Hz}$, $J=11.4 \mathrm{~Hz}, J=3.2 \mathrm{~Hz}), 1.96(1 \mathrm{H}, \mathrm{m}), 2.01(1 \mathrm{H}, \mathrm{dt}, J=13.1 \mathrm{~Hz}, J=$ $4.1 \mathrm{~Hz}), 2.32(2 \mathrm{H}, \mathrm{dt}, J=5.0 \mathrm{~Hz}, J=7.2 \mathrm{~Hz}), 2.39(2 \mathrm{H}, \mathrm{m}), 3.41$ (ddd, $J=11.4 \mathrm{~Hz}, J=9.6 \mathrm{~Hz}, J=4.6 \mathrm{~Hz}), 3.52(1 \mathrm{H}, \mathrm{m}), 3.62(1 \mathrm{H}$, $\mathrm{m}), 3.68(1 \mathrm{H}, \mathrm{dq}, J=9.7 \mathrm{~Hz}, J=6.3 \mathrm{~Hz}), 3.72(1 \mathrm{H}, \mathrm{s.br}), 3.80(1 \mathrm{H}$, $\mathrm{m}), 3.83(1 \mathrm{H}, \mathrm{m}), 4.65(1 \mathrm{H}, \mathrm{s}), 4.71(1 \mathrm{H}, \mathrm{s}), 4.79(1 \mathrm{H}, \mathrm{s.br})$ (Table S2 $\dagger$ ); ESI-(-)-HR-MS: obs. $m / z 477.2348[\mathrm{M}-\mathrm{H}]^{-}$, calc. $m / z$ 477.2341 for $\mathrm{C}_{22} \mathrm{H}_{37} \mathrm{O}_{11}$ (Table $\mathrm{S} 1 \dagger$ ).

$(4 R)$-4-[[3,6-Dideoxy-2-O-[(5R)-5-[(3,6-dideoxy- $\alpha$-L-arabino-hexopyranosyl)oxy]-1-oxo-hexyl]- $\alpha$-L-arabino-hexopyranosyl]oxy]-pentanoic acid (2'-(asc-C6)-asc-C5, 7) enriched from the C. nigoni JU1422 exometabolome (approximately $100 \mu \mathrm{g}$ ) along with dominating asc- $\Delta \mathrm{C} 9 ;{ }^{1} \mathrm{H}$ NMR $\left(400 \mathrm{MHz}, \mathrm{CD}_{3} \mathrm{OD}\right) \delta 1.14(3 \mathrm{H}, \mathrm{d}, J=$ $6.2 \mathrm{~Hz}), 1.14(3 \mathrm{H}, \mathrm{d}, J=6.3 \mathrm{~Hz}), 1.22(3 \mathrm{H}, \mathrm{d}, J=6.2 \mathrm{~Hz}), 1.22(3 \mathrm{H}$, $\mathrm{d}, J=6.2 \mathrm{~Hz}), 1.56(2 \mathrm{H}, \mathrm{m}), 1.70(1 \mathrm{H}, \mathrm{m}), 1.77(1 \mathrm{H}, \mathrm{ddd}, J=13.3$ $\mathrm{Hz}, J=11.4 \mathrm{~Hz}, J=3.0 \mathrm{~Hz}), 1.80(3 \mathrm{H}, \mathrm{m}), 1.90(1 \mathrm{H}, \mathrm{ddd}, J=13.3$ $\mathrm{Hz}, J=11.2 \mathrm{~Hz}, J=3.4 \mathrm{~Hz}), 1.96(1 \mathrm{H}, \mathrm{dt}, J=13.1 \mathrm{~Hz}, J=4.1 \mathrm{~Hz})$, $2.01(1 \mathrm{H}, \mathrm{dt}, J=13.2 \mathrm{~Hz}, J=3.9 \mathrm{~Hz}), 2.32(2 \mathrm{H}, \mathrm{m}), 2.39(2 \mathrm{H}, \mathrm{dt}, J$ $=3.1 \mathrm{~Hz}, J=7.4 \mathrm{~Hz}), 3.40(\mathrm{ddd}, J=11.5 \mathrm{~Hz}, J=9.7 \mathrm{~Hz}, J=4.9$ $\mathrm{Hz}), 3.52(1 \mathrm{H}, \mathrm{ddd}, J=11.3 \mathrm{~Hz}, J=9.6 \mathrm{~Hz}, J=4.7 \mathrm{~Hz}), 3.62(1 \mathrm{H}$, $\mathrm{dq}, J=9.5 \mathrm{~Hz}, J=6.2 \mathrm{~Hz}), 3.71(1 \mathrm{H}, \mathrm{dq}, J=9.7 \mathrm{~Hz}, J=6.3 \mathrm{~Hz})$, $3.73(1 \mathrm{H}, \mathrm{s.br}), 3.81(1 \mathrm{H}, \mathrm{m}), 3.83(1 \mathrm{H}, \mathrm{m}), 4.65(1 \mathrm{H}, \mathrm{s}), 4.71(1 \mathrm{H}$, s), 4.79 (1H, s.br) (Table S2†); ESI-(-)-HR-MS: obs. $m / z 491.2495$ $[\mathrm{M}-\mathrm{H}]^{-}$, calc. $m / z 491.2498$ for $\mathrm{C}_{23} \mathrm{H}_{39} \mathrm{O}_{11}$ (Table $\mathrm{S} 1 \dagger$ ).

$(5 R)-5$-[[3,6-Dideoxy-2-O-[(5R)-5-[(3,6-dideoxy- $\alpha$-L-arabino-hexopyranosyl)oxy]-1-oxo-hexyl]- $\alpha$-L-arabino-hexopyranosyl]oxy]-hexanoic acid (2'-(asc-C6)-asc-C6, 8) isolated from the C. nigoni JU1422 exometabolome (approximately $100 \mu \mathrm{g}$ ) along with minor amounts of asc-C9; ${ }^{1} \mathrm{H}$ NMR $\left(400 \mathrm{MHz}, \mathrm{CD}_{3} \mathrm{OD}\right) \delta 1.14$ $(3 \mathrm{H}, \mathrm{d}, J=6.3 \mathrm{~Hz}), 1.14(3 \mathrm{H}, \mathrm{d}, J=6.3 \mathrm{~Hz}), 1.22(3 \mathrm{H}, \mathrm{d}, J=6.2$
$\mathrm{Hz}), 1.22(3 \mathrm{H}, \mathrm{d}, J=6.2 \mathrm{~Hz}), 1.57(4 \mathrm{H}, \mathrm{m}), 1.65(1 \mathrm{H}, \mathrm{m}), 1.69$ $(1 \mathrm{H}, \mathrm{m}), 1.76(1 \mathrm{H}, \mathrm{m}), 1.77(1 \mathrm{H}, \mathrm{ddd}, J=13.0 \mathrm{~Hz}, J=11.5 \mathrm{~Hz}, J$ $=3.1 \mathrm{~Hz}), 1.79(1 \mathrm{H}, \mathrm{m}), 1.89(1 \mathrm{H}, \mathrm{ddd}, J=13.4 \mathrm{~Hz}, J=11.5 \mathrm{~Hz}$, $J=3.3 \mathrm{~Hz}), 1.95(1 \mathrm{H}, \mathrm{dt}, J=13.2 \mathrm{~Hz}, J=3.9 \mathrm{~Hz}), 2.00(1 \mathrm{H}, \mathrm{dt}, J$ $=13.3 \mathrm{~Hz}, J=3.9 \mathrm{~Hz}), 2.32(2 \mathrm{H}, \mathrm{t}, J=7.2 \mathrm{~Hz}), 2.39(2 \mathrm{H}, \mathrm{dt}, J=$ $3.0 \mathrm{~Hz}, J=7.5 \mathrm{~Hz}), 3.40(\mathrm{ddd}, J=11.5 \mathrm{~Hz}, J=9.7 \mathrm{~Hz}, J=4.9$ $\mathrm{Hz}), 3.51(1 \mathrm{H}, \mathrm{ddd}, J=11.5 \mathrm{~Hz}, J=9.7 \mathrm{~Hz}, J=4.9 \mathrm{~Hz}), 3.62(1 \mathrm{H}$, $\mathrm{dq}, J=9.7 \mathrm{~Hz}, J=6.3 \mathrm{~Hz}), 3.70(1 \mathrm{H}, \mathrm{dq}, J=9.7 \mathrm{~Hz}, J=6.3 \mathrm{~Hz})$, $3.72(1 \mathrm{H}, \mathrm{s.br}), 3.79(1 \mathrm{H}, \mathrm{m}), 3.80(1 \mathrm{H}, \mathrm{m}), 4.65(1 \mathrm{H}, \mathrm{s}), 4.71$ $(1 \mathrm{H}, \mathrm{s}), 4.78(1 \mathrm{H}, \mathrm{s} . b r)$ (Table S2†); ESI-(-)-HR-MS: obs. $\mathrm{m} / \mathrm{z}$ $505.2664[\mathrm{M}-\mathrm{H}]^{-}$, calc. $m / z \quad 505.2654$ for $\mathrm{C}_{24} \mathrm{H}_{41} \mathrm{O}_{11}$ (Table S1 $\dagger$ ).

\section{Holding assay to evaluate nematode behavioural response}

Nematode preference for environments conditioned with 100 fmol of ascaroside dimers was measured using a modified holding assay. On a $6 \mathrm{~cm}$ Petri dish filled with $6 \mathrm{ml}$ peptonefree nematode growth medium (NGM) agar, circular scoring regions of $9 \mathrm{~mm}$ diameter were marked. Next, $1 \mu \mathrm{l}$ of $10 \%$ aqueous methanol ( $\mathrm{v} / \mathrm{v}$, as solvent control) or $100 \mathrm{nM}$ solutions of ascaroside dimers such as natural 4'-(asc-C4)-asc-C5 (5) isolated from C. remanei PB4641, synthetic 2'-(asc-C6)-asc-C5 (7) and $2^{\prime}$-(asc-C6)-asc-C6 (8) identical to the natural products isolated from C. nigoni JU1422, or their synthetic 4-isomers 4'(asc-C6)-asc-C5 (13a) and 4'-(asc-C6)-asc-C6 (13b) in 10\% aqueous methanol $(\mathrm{v} / \mathrm{v})$ were placed in the centre of the scoring areas onto the agar and left to dry for 5 minutes. Young adult nematodes from non-starved and non-crowded $6 \mathrm{~cm}$ NGM agar plates seeded with $E$. coli OP50 were sorted by sex and transferred to peptone-free unseeded NGM agar plates for approximately $30 \mathrm{~min}$ before being used for the assay to minimize the amount of concomitant bacteria. Individual worms (up to 3) were placed into the centre of the conditioned scoring region and the time required for the nematodes to leave the scoring region was recorded. Nematodes were defined to have left the scoring area when no part of the nematode was still within the circular boundary. A total number of 20 worms per condition were analysed and experiments were repeated on two separate days with comparable results. A oneway ANOVA with Dunett's post-test was performed using the SPSS statistics software version 26 (IBM) to evaluate the effect of ascaroside dimers versus solvent control on mean times nematode spent in scoring regions.

$(3 R)-3$-[(2,4-Di-O-benzoyL-3,6-dideoxy- $\alpha$-L-arabino-hexopyranosyl)oxy]-1-butene (10a). A solution of 2,4-di-O-benzoyL-3,6dideoxy- $\alpha$-L-arabino-hexopyranose $(\mathbf{9}, 395 \mathrm{mg}, 1.11 \mathrm{mmol}$ ) (synthesized in 6 steps from L-rhamnose $\left.{ }^{25,26}\right)$ in dry dichloromethane $(15 \mathrm{ml})$ was treated with trichloroacetonitrile $(222 \mu \mathrm{L}$, $2.22 \mathrm{mmol}$ ) and 1,8-diazabicyclo[5.4.0]undec-7-ene (DBU, $16 \mu \mathrm{L} 0.11 \mathrm{mmol}$ ). After stirring for $30 \mathrm{~min}$, the solution was concentrated under reduced pressure and the residue was quickly chromatographed over a short column of silica gel using $10 \%(\mathrm{v} / \mathrm{v})$ ethyl acetate in hexane as eluent to afford 2,4di-O-benzoyl-3,6-dideoxy- $\alpha$-L-arabino-hexopyranosyl-1-(2,2,2-trichloroethanimidate) ( $462 \mathrm{mg}, 0.92 \mathrm{mmol}, 83 \%$ yield) as a colourless oil that was immediately used for the next step. 
A solution of 2,4-di-O-benzoyl-3,6-dideoxy- $\alpha$-L-arabino-hexopyranosyl-1-(2,2,2-trichloroethanimidate) (462 $\mathrm{mg}, 0.92 \mathrm{mmol}$ ) and (R)-(-)-3-butene-2-ol (104 mg, $1.44 \mathrm{mmol}$ ) in dry dichloromethane $(15 \mathrm{~mL})$ at $0{ }^{\circ} \mathrm{C}$ was treated with catalytic amounts of trimethylsilyl triflate $(5 \mu \mathrm{L})$. After stirring at $0{ }^{\circ} \mathrm{C}$ for $1 \mathrm{~h}$ and another $3 \mathrm{~h}$ at room temperature the mixture was concentrated under reduced pressure and fractionated by column chromatography on silica gel using $2.5 \%(\mathrm{v} / \mathrm{v})$ ethyl acetate in toluene as eluent to afford (3R)-3-[(2,4-di-O-benzoyl-3,6-dideoxy- $\alpha-\mathrm{L}-$ arabino-hexopyranosyl)oxy]-1-butene (10a, $297 \mathrm{mg}, 0.72 \mathrm{mmol}$, $78 \%$ yield) as a colourless oil. ${ }^{1} \mathrm{H}$ NMR (400 $\left.\mathrm{MHz}, \mathrm{CD}_{3} \mathrm{OD}\right) \delta$ $1.26(3 \mathrm{H}, \mathrm{d}, J=6.2 \mathrm{~Hz}), 1.31(3 \mathrm{H}, \mathrm{d}, J=6.4 \mathrm{~Hz}), 2.23(1 \mathrm{H}, \mathrm{m})$, $2.42(1 \mathrm{H}, \mathrm{td}, J=13.5 \mathrm{~Hz}, J=3.8 \mathrm{~Hz}), 4.13(1 \mathrm{H}, \mathrm{dq}, J=9.7 \mathrm{~Hz}, J$ = $6.1 \mathrm{~Hz}), 4.31(1 \mathrm{H}, \mathrm{m}), 4.98(1 \mathrm{H}, \mathrm{s}), 5.14(1 \mathrm{H}, \mathrm{d}, J=10.3 \mathrm{~Hz})$, $5.19(2 \mathrm{H}, \mathrm{m}), 5.28$ (1H, d, $J=17.2 \mathrm{~Hz}), 5.96$ (1H, ddd, $J=6.3$ $\mathrm{Hz}, J=10.6 \mathrm{~Hz}, J=17.1 \mathrm{~Hz}), 7.47(4 \mathrm{H}, \mathrm{m}), 7.59(2 \mathrm{H}, \mathrm{m}), 8.04$ $(2 \mathrm{H}, \mathrm{d}, J=7.2 \mathrm{~Hz}), 8.11(2 \mathrm{H}, \mathrm{d}, J=7.1 \mathrm{~Hz}) ;{ }^{13} \mathrm{C}\left\{{ }^{1} \mathrm{H}\right\} \mathrm{NMR}$ (100 MHz, $\left.\mathrm{CD}_{3} \mathrm{OD}\right) \delta 17.7,19.9,29.7,66.9,70.6,70.9,74.3$, 94.6, 114.8, 128.4 (4C), 129.6 (2C), 129.9 (2C), 130.0, 133.15, 133.24, 140.1, 165.7, 165.8; ESI-(+)-HR-MS: obs. $\mathrm{m} / \mathrm{z} 433.1631$ $[\mathrm{M}+\mathrm{Na}]^{+}$, calc. $m / z 433.1622$ for $\mathrm{C}_{24} \mathrm{H}_{26} \mathrm{NaO}_{6}$.

(4R)-4-[(2,4-Di-O-benzoyl-3,6-dideoxy- $\alpha$-L-arabino-hexopyranosyl) oxy]-1-pentene (10b). A solution of 2,4-di-O-benzoyl-3,6-dideoxy$\alpha$-L-arabino-hexopyranosyl-1-(2,2,2-trichloroethanimidate) (462 mg, $0.92 \mathrm{mmol}$; see 10a for its preparation) and (R)-(-)-4-pentene-2-ol $(126 \mathrm{mg}, 1.46 \mathrm{mmol})$ in dry dichloromethane $(15 \mathrm{~mL})$ at $0{ }^{\circ} \mathrm{C}$ was treated with catalytic amounts of trimethylsilyl triflate $(5 \mu \mathrm{L})$. After stirring at $0{ }^{\circ} \mathrm{C}$ for $1 \mathrm{~h}$ and another $3 \mathrm{~h}$ at room temperature the mixture was concentrated under reduced pressure. The residue was fractionated by column chromatography on silica gel using $2.5 \%(\mathrm{v} / \mathrm{v})$ ethyl acetate in toluene as eluent to afford (4R)-4-[(2,4-di-O-benzoyl-3,6-dideoxy- $\alpha-\mathrm{L}^{-}$ arabino-hexopyranosyl)oxy]-1-pentene (10b, $332 \mathrm{mg}$, $0.78 \mathrm{mmol}, 85 \%$ yield) as a colourless oil. ${ }^{1} \mathrm{H}$ NMR $(400 \mathrm{MHz}$, $\left.\mathrm{CD}_{3} \mathrm{OD}\right) \delta 1.20(3 \mathrm{H}, \mathrm{d}, J=6.1 \mathrm{~Hz}), 1.24(3 \mathrm{H}, \mathrm{d}, J=6.2 \mathrm{~Hz}), 2.19$ $(1 \mathrm{H}, \mathrm{ddd}, J=13.5 \mathrm{~Hz}, J=11.3 \mathrm{~Hz}, J=2.8 \mathrm{~Hz}), 2.31(1 \mathrm{H}, \mathrm{m})$, $2.40(2 \mathrm{H}, \mathrm{m}), 3.92(1 \mathrm{H}, \mathrm{tq}, J=9.2 \mathrm{~Hz}, J=6.1 \mathrm{~Hz}), 4.20(1 \mathrm{H}, \mathrm{dq}$, $J=9.7 \mathrm{~Hz}, J=6.2 \mathrm{~Hz}), 4.96(1 \mathrm{H}, \mathrm{s}), 5.12(4 \mathrm{H}, \mathrm{m}), 5.92(1 \mathrm{H}, \mathrm{ddt}$, $J=17.2 \mathrm{~Hz}, J=9.9 \mathrm{~Hz}, J=7.2 \mathrm{~Hz}), 7.50(4 \mathrm{H}, \mathrm{m}), 7.62(2 \mathrm{H}, \mathrm{m})$, $8.01(2 \mathrm{H}, \mathrm{d}, J=7.2 \mathrm{~Hz}), 8.09(2 \mathrm{H}, \mathrm{d}, J=7.2 \mathrm{~Hz}) ;{ }^{13} \mathrm{C}\left\{{ }^{1} \mathrm{H}\right\} \mathrm{NMR}$ (100 MHz, $\left.\mathrm{CD}_{3} \mathrm{OD}\right) \delta 18.1,19.3,30.6,42.7,68.2$, 72.0, 72.7, 73.8, 95.2, 117.6, 129.7 (4C), 130.5 (2C), 130.7 (2C), 131.2, 134.48, 134.54, 136.3, 167.0, 167.1; ESI-(+)-HR-MS: obs. $\mathrm{m} / \mathrm{z}$ $447.1782[\mathrm{M}+\mathrm{Na}]^{+}$, calc. $m / z 447.1778$ for $\mathrm{C}_{25} \mathrm{H}_{28} \mathrm{NaO}_{6}$.

Benzyl $\quad(2 E, 4 R)-4-[(3,6$-dideoxy- $\alpha$-L-arabino-hexopyranosyl) oxy]-2-pentenoate (11a). A solution of (3R)-3-[(2,4-di-O-benzoyl3,6-dideoxy- $\alpha$-L-arabino-hexopyranosyl)oxy]-1-butene (10a, $180 \mathrm{mg}, 0.439 \mathrm{mmol})$ in methanol $(1.8 \mathrm{ml})$ was treated with $820 \mu \mathrm{L}$ of saturated aqueous lithium hydroxide (105 mg, $4.39 \mathrm{mmol}$ ) solution. The mixture was stirred for $12 \mathrm{~h}$ at room temperature, the $\mathrm{pH}$ neutralized with acetic acid, and the solution concentrated under reduced pressure. The product was purified by column chromatography on silica gel using $10 \%$ methanol $(\mathrm{v} / \mathrm{v})$ in dichloromethane as eluent to afford (3R)-3[(3,6-dideoxy- $\alpha$-L-arabino-hexopyranosyl)oxy]-1-butene $(64.7 \mathrm{mg}$, $0.320 \mathrm{mmol}, 73 \%$ yield) as a colourless oil. ${ }^{1} \mathrm{H}$ NMR $(400 \mathrm{MHz}$,
$\left.\mathrm{CD}_{3} \mathrm{OD}\right) \delta 1.19(3 \mathrm{H}, \mathrm{d}, J=6.2 \mathrm{~Hz}), 1.22(3 \mathrm{H}, \mathrm{d}, J=6.4 \mathrm{~Hz}), 1.79$ $(1 \mathrm{H}, \mathrm{ddd}, J=13.2 \mathrm{~Hz}, J=11.2 \mathrm{~Hz}, J=3.1 \mathrm{~Hz}), 1.95(1 \mathrm{H}, \mathrm{ddd}, J=$ $13.1 \mathrm{~Hz}, J=3.9 \mathrm{~Hz}, J=3.9 \mathrm{~Hz}), 3.51(1 \mathrm{H}$, ddd, $J=11.1 \mathrm{~Hz}, J=$ $9.5 \mathrm{~Hz}, J=4.6 \mathrm{~Hz}), 3.61(1 \mathrm{H}, \mathrm{qd}, J=9.3 \mathrm{~Hz}, J=6.0 \mathrm{~Hz}), 3.75$ $(1 \mathrm{H}, \mathrm{br} \mathrm{s}), 4.23(1 \mathrm{H}, \mathrm{qd}, J=6.3 \mathrm{~Hz}, J=6.4 \mathrm{~Hz}), 4.66(1 \mathrm{H}, \mathrm{s})$, $5.06(1 \mathrm{H}, \mathrm{ddd}, J=10.5 \mathrm{~Hz}, J=1.6 \mathrm{~Hz}, J=1.6 \mathrm{~Hz}), 5.22(1 \mathrm{H}$, ddd $J=17.3 \mathrm{~Hz}, J=J=1.5 \mathrm{~Hz}), 5.90(1 \mathrm{H}, \operatorname{ddd}, J=17.2 \mathrm{~Hz}, J=$ $10.5 \mathrm{~Hz}, J=6.1 \mathrm{~Hz}$ ); ESI-(+)-HR-MS: obs. $m / z 225.1103[\mathrm{M}+$ $\mathrm{Na}]^{+}$, calc. $m / z 225.1097$ for $\mathrm{C}_{10} \mathrm{H}_{18} \mathrm{NaO}_{4}$.

A solution of (3R)-3-[(3,6-dideoxy- $\alpha$-L-arabino-hexopyranosyl) oxy]-1-butene $(64.7 \mathrm{mg} 0.320 \mathrm{mmol})$ in dry dichloromethane $(6.5 \mathrm{ml})$ was treated with benzyl acrylate $(240 \mu \mathrm{L}, 259.6 \mathrm{mg}$, $1.6 \mathrm{mmol}$ ) and Grubbs 2nd generation catalyst $(27.2 \mathrm{mg}$, $32.0 \mu \mathrm{mol}, 10 \mathrm{~mol} \%$ ). After stirring at reflux for $6 \mathrm{~h}$ the solution was concentrated under reduced pressure and the residue fractionated on silica gel using $5 \%(\mathrm{v} / \mathrm{v})$ methanol in dichloromethane as eluent to afford benzyl $(2 E, 4 R)-4$-[(3,6-dideoxy- $\alpha$-Larabino-hexopyranosyl)oxy]-2-pentenoate (11a, $51.2 \mathrm{mg}$, $0.152 \mathrm{mmol}, 48 \%$ yield) as a colourless oil. ${ }^{1} \mathrm{H}$ NMR $(400 \mathrm{MHz}$, $\left.\mathrm{CD}_{3} \mathrm{OD}\right) \delta 1.15(3 \mathrm{H}, \mathrm{d}, J=5.80 \mathrm{~Hz}), 1.28(3 \mathrm{H}, \mathrm{d}, J=6.6 \mathrm{~Hz}), 1.79$ $(1 \mathrm{H}, \mathrm{ddd}, J=13.3 \mathrm{~Hz}, J=10.9 \mathrm{~Hz}, J=3.1 \mathrm{~Hz}), 1.96(1 \mathrm{H}, \mathrm{m})$, 3.52 (2H, m), 3.78 (1H, br.s), $4.44(1 \mathrm{H}, \mathrm{m}), 4.68(1 \mathrm{H}, \mathrm{s}), 5.18$ $(2 \mathrm{H}, \mathrm{s}), 6.07(1 \mathrm{H}, \mathrm{dd}, J=15.8 \mathrm{~Hz}, J=1.7 \mathrm{~Hz}), 6.99(1 \mathrm{H}, \mathrm{dd}, J=$ $15.7 \mathrm{~Hz}, J=5.4 \mathrm{~Hz}), 7.34(5 \mathrm{H}, \mathrm{m}) ;{ }^{13} \mathrm{C}\left\{{ }^{1} \mathrm{H}\right\} \mathrm{NMR}(100 \mathrm{MHz}$, $\left.\mathrm{CD}_{3} \mathrm{OD}\right) \delta 17.9,19.6,36.0,67.3,68.2,69.6,71.4,72.4,98.6$, 120.6, 129.26, 129.31 (2C), 129.6 (2C), 151.6, 167.8; ESI(+)-HR-MS: obs. $m / z$ 359.1474 [M + Na $]^{+}$, calc. $m / z 359.1465$ for $\mathrm{C}_{18} \mathrm{H}_{24} \mathrm{NaO}_{6}$.

Benzyl (2E,5R)-5-[(3,6-dideoxy- $\alpha$-L-arabino-hexopyranosyl) oxy]-2-hexenoate (11b). A solution of $(4 R)-4$-[(2,4-di-O-benzoyl3,6-dideoxy- $\alpha$-L-arabino-hexopyranosyl)oxy]-1-pentene (10b, $200 \mathrm{mg}, 0.471 \mathrm{mmol})$ in methanol $(2 \mathrm{~mL})$ was treated with $881 \mu \mathrm{L}$ of saturated aqueous lithium hydroxide (112 mg, $4.71 \mathrm{mmol}$ ) solution. The mixture was stirred for $12 \mathrm{~h}$ at room temperature, the $\mathrm{pH}$ neutralized with acetic acid, and the solution concentrated under reduced pressure. The product was purified by column chromatography on silica gel using $10 \%$ $(\mathrm{v} / \mathrm{v})$ methanol in dichloromethane as eluent to afford (4R)-4[(3,6-dideoxy- $\alpha$-L-arabino-hexopyranosyl)oxy]-1-pentene $(88.8 \mathrm{mg}$, $0.411 \mathrm{mmol}, 87 \%$ yield) as a colourless oil. ${ }^{1} \mathrm{H}$ NMR $(400 \mathrm{MHz}$, $\left.\mathrm{CD}_{3} \mathrm{OD}\right) \delta 1.13(3 \mathrm{H}, \mathrm{d}, J=6.1 \mathrm{~Hz}), 1.20(3 \mathrm{H}, \mathrm{d}, J=6.2 \mathrm{~Hz}), 1.76$ $(1 \mathrm{H}, \mathrm{ddd}, J=13.1 \mathrm{~Hz}, J=11.3 \mathrm{~Hz}, J=3.1 \mathrm{~Hz}), 1.95(1 \mathrm{H}, \mathrm{ddd}, J=$ $12.8 \mathrm{~Hz}, J=3.3 \mathrm{~Hz}, J=0.9 \mathrm{~Hz}), 2.28(2 \mathrm{H}, \mathrm{m}), 3.51(1 \mathrm{H}, \mathrm{ddd}, J=$ $11.3 \mathrm{~Hz}, J=9.5 \mathrm{~Hz}, J=4.6 \mathrm{~Hz}), 3.65(1 \mathrm{H}, \mathrm{dq}, J=9.5 \mathrm{~Hz}, J=$ $6.4 \mathrm{~Hz}), 3.72(1 \mathrm{H}, \mathrm{br} s), 3.82(1 \mathrm{H}, \mathrm{m}), 4.64(1 \mathrm{H}, \mathrm{s}), 5.06(2 \mathrm{H}$, m), 5.88 (1H, ddt, $J=17.2 \mathrm{~Hz}, J=10.3 \mathrm{~Hz}, J=7.2 \mathrm{~Hz}$ ); ESI-(+)HR-MS: obs. $m / z 239.1266[\mathrm{M}+\mathrm{Na}]^{+}$, calc. $m / z 239.1254$ for $\mathrm{C}_{11} \mathrm{H}_{20} \mathrm{NaO}_{4}$.

A solution of $(4 R)-4$-[(3,6-dideoxy- $\alpha$-L-arabino-hexopyranosyl) oxy]-1-pentene (98.8 $\mathrm{mg} 0.457 \mathrm{mmol}$ ) in dry dichloromethane $(10 \mathrm{~mL})$ was treated with benzyl acrylate $(343 \mu \mathrm{L}, 370 \mathrm{mg}$, $2.28 \mathrm{mmol}$ ) and Grubbs 2nd generation catalyst $(38.8 \mathrm{mg}$, $45.7 \mu \mathrm{mol}, 10 \mathrm{~mol} \%)$. After stirring at reflux for $6 \mathrm{~h}$ the solution was concentrated under reduced pressure and the residue fractionated on silica gel using $5 \%$ methanol in dichloromethane $(\mathrm{v} / \mathrm{v})$ as eluent to afford benzyl $(2 E, 5 R)-5$-[(3,6-dideoxy- 
$\alpha$-L-arabino-hexopyranosyl)oxy]-2-hexenoate $(\mathbf{1 1 b}, 118.9 \mathrm{mg}$ $0.339 \mathrm{mmol}, 74 \%$ yield) as a colourless oil. ${ }^{1} \mathrm{H}$ NMR $(400 \mathrm{MHz}$, $\left.\mathrm{CD}_{3} \mathrm{OD}\right) \delta 1.16(3 \mathrm{H}, \mathrm{d}, J=5.9 \mathrm{~Hz}), 1.17(3 \mathrm{H}, \mathrm{d}, J=6.1 \mathrm{~Hz}), 1.74$ $(1 \mathrm{H}, \mathrm{ddd}, J=13.1 \mathrm{~Hz}, J=11.0 \mathrm{~Hz}, J=2.9 \mathrm{~Hz}), 1.94(1 \mathrm{H}, \mathrm{dt}, J=$ $12.9 \mathrm{~Hz}, J=3.9 \mathrm{~Hz}), 2.45(2 \mathrm{H}, \mathrm{m}), 3.50(1 \mathrm{H}, \mathrm{ddd}, J=11.1 \mathrm{~Hz}, J$ $=9.4 \mathrm{~Hz}, J=4.5 \mathrm{~Hz}), 3.59(1 \mathrm{H}, \mathrm{dq}, J=9.6 \mathrm{~Hz}, J=6.0 \mathrm{~Hz}), 3.72$ (1H, br.s), 3.94 (1H, m), 4.63 (1H, s), 5.17 (2H, s), 5.97 (1H, d, J $=15.7 \mathrm{~Hz}), 7.05(1 \mathrm{H}, \mathrm{dt}, J=15.6 \mathrm{~Hz}, J=7.3 \mathrm{~Hz}), 7.35(5 \mathrm{H}, \mathrm{m})$; ${ }^{13} \mathrm{C}\left\{{ }^{1} \mathrm{H}\right\}$ NMR (100 MHz, CD $\left.3 \mathrm{OD}\right) \delta 18.1,19.5,35.9,40.8,67.2$, 68.3, 69.9, 71.4, 72.4, 98.2, 124.0, 129.18, 129.21 (2C), 129.5 (2C), 147.9, 167.7; ESI-(+)-HR-MS: obs. $m / z$ 373.1629 [M + Na $]^{+}$, calc. $m / z 373.1622$ for $\mathrm{C}_{19} \mathrm{H}_{26} \mathrm{NaO}_{6}$.

(5R)-5-[(2,4-Di-O-tert-butyldimethylsilyl-3,6-dideoxy- $\alpha$-L-arabinohexopyranosyl)oxy]-hexanoic acid (12). A solution of benzyl $(2 E, 5 R)-5$-[(3,6-dideoxy- $\alpha$-L-arabino-hexopyranosyl)oxy]-2-hexenoate (11b, $55 \mathrm{mg}, 157 \mu \mathrm{mol})$ in dry dichloromethane $(5 \mathrm{~mL})$ was treated with imidazole $(53 \mathrm{mg}, 785 \mu \mathrm{mol})$ and tert-butyldimethylsilyl chloride (118 mg, $785 \mu \mathrm{mol})$. After stirring overnight, the reaction was quenched with water $(1 \mathrm{~mL})$ and the organic phase dried over sodium sulphate and concentrated under reduced pressure. The residue was fractionated by column chromatography on silica gel using $15 \%(\mathrm{v} / \mathrm{v})$ ethyl acetate in hexane as eluent to afford benzyl $(2 E, 5 R)-5$-[(2,4-di-O-tertbutyldimethylsilyl-3,6-dideoxy- $\alpha$-L-arabino-hexopyranosyl)oxy]2-hexenoate (40 mg, $69.1 \mu \mathrm{mol}, 44 \%$ yield) as a colourless oil. ${ }^{1} \mathrm{H}$ NMR (400 MHz, CD $\left.3 \mathrm{OD}\right) \delta 0.07$ (12H, m), 0.89 (9H, s), 0.92 $(9 \mathrm{H}, \mathrm{s}), 1.12(3 \mathrm{H}, \mathrm{d}, J=6.0 \mathrm{~Hz}), 1.14(3 \mathrm{H}, \mathrm{d}, J=6.2 \mathrm{~Hz}), 1.74(1 \mathrm{H}$, ddd, $J=12.9 \mathrm{~Hz}, J=10.2 \mathrm{~Hz}, J=2.7 \mathrm{~Hz}), 1.82(1 \mathrm{H}, \mathrm{ddd}, J=12.9$ $\mathrm{Hz}, J=J=3.7 \mathrm{~Hz}$ ), $2.43(2 \mathrm{H}$, ddd $J=7.3 \mathrm{H} \mathrm{z}, J=6.2 \mathrm{~Hz}, J=1.2$ $\mathrm{Hz}), 3.59$ (1H, dq, $J=8.9 \mathrm{~Hz}, J=5.9 \mathrm{~Hz}), 3.65(1 \mathrm{H}, \mathrm{ddd}, J=9.9$ $\mathrm{Hz}, J=9.2 \mathrm{~Hz}, J=4.3 \mathrm{~Hz}), 3.80(1 \mathrm{H}, \mathrm{br} . \mathrm{s}), 3.92(1 \mathrm{H}, \mathrm{tq}, J=6.2 \mathrm{~Hz}$, $J=6.1 \mathrm{~Hz}), 4.53(1 \mathrm{H}, \mathrm{s}), 5.13(1 \mathrm{H}, \mathrm{d}, J=12.5 \mathrm{~Hz}), 5.17(1 \mathrm{H}, \mathrm{d}, J=$ $12.5 \mathrm{~Hz}), 5.96(1 \mathrm{H}, \mathrm{dt}, J=15.7 \mathrm{~Hz}, J=1.7 \mathrm{~Hz}), 7.03(1 \mathrm{H}, \mathrm{dt}, J=$ $15.5 \mathrm{~Hz}, J=7.4 \mathrm{~Hz}), 7.32(5 \mathrm{H}, \mathrm{m}) ;{ }^{13} \mathrm{C}\left\{{ }^{1} \mathrm{H}\right\}$ NMR $(100 \mathrm{MHz}$, $\left.\mathrm{CD}_{3} \mathrm{OD}\right) \delta-4.71(2 \mathrm{C}),-4.4,-3.8,18.6,18.8,18.9,19.6,26.3,26.4$ (3C), 37.9, 40.8, 67.1, 70.1, 71.2, 71.6, 72.7, 98.3, 124.1, 129.14 (2C), 129.15, 129.5 (2C), 137.6, 147.9, 167.5; ESI-(+)-HR-MS: obs. $m / z 601.3334[\mathrm{M}+\mathrm{Na}]^{+}$, calc. $m / z 601.3351$ for $\mathrm{C}_{31} \mathrm{H}_{54} \mathrm{NaO}_{6} \mathrm{Si}_{2}$.

A solution of benzyl $(2 E, 5 R)-5$-[(2,4-di-O-tert-butyldimethylsilyl-3,6-dideoxy- $\alpha$-L-arabino-hexopyranosyl)oxy]-2-hexenoate (40 mg, $69.1 \mu \mathrm{mol})$ in $\mathrm{MeOH}(0.5 \mathrm{~mL})$ was treated with $10 \mathrm{~mol} \%$ palladium on carbon $(20 \mathrm{mg})$ and hydrogenated under $\mathrm{H}_{2}$ atmosphere ( $\left.1 \mathrm{~atm}\right)$. After stirring for $4 \mathrm{~h}$ the catalyst was removed by filtration over Celite and the product was obtained after concentration under reduced pressure to afford (5R)-5-[(2,4-di-O-tert-butyldimethylsilyl-3,6-dideoxy- $\alpha$-L-arabinohexopyranosyl)oxy]-hexanoic acid (12, $32.7 \mathrm{mg}, 66.7 \mu \mathrm{mol}, 96 \%$ yield) as a colourless oil. ${ }^{1} \mathrm{H}$ NMR (400 MHz, CD 3 OD) $\delta 0.09$ $(12 \mathrm{H}, \mathrm{m}), 0.91(9 \mathrm{H}, \mathrm{s}), 0.92(9 \mathrm{H}, \mathrm{s}), 1.13(3 \mathrm{H}, \mathrm{d}, J=6.1 \mathrm{~Hz})$, $1.17(3 \mathrm{H}, \mathrm{d}, J=6.0 \mathrm{~Hz}), 1.45-1.78(3 \mathrm{H}, \mathrm{m}), 1.85(1 \mathrm{H}, \mathrm{ddd}, J=$ $12.7 \mathrm{~Hz}, J=J=3.8 \mathrm{~Hz}), 2.31(2 \mathrm{H}, \mathrm{td}, J=7.7 \mathrm{~Hz}, J=2.4 \mathrm{~Hz}), 3.63$ $(1 \mathrm{H}, \mathrm{m}), 3.67(1 \mathrm{H}, \mathrm{m}), 3.79(1 \mathrm{H}, \mathrm{m}), 3.80(1 \mathrm{H}, \mathrm{s.br}), 4.54(1 \mathrm{H}$, $\mathrm{s}) ;{ }^{13} \mathrm{C}\left\{{ }^{1} \mathrm{H}\right\} \mathrm{NMR}\left(100 \mathrm{MHz}, \mathrm{CD}_{3} \mathrm{OD}\right) \delta-4.80,-4.78,-4.4$, $-3.9,18.5,18.8,18.9,19.2,26.25$ (3C), 26.30 (3C), 31.3, 33.4, 38.0, 70.2, 71.3, 71.6, 71.7, 97.8, 177.4; ESI-(+)-HR-MS: obs. $\mathrm{m} / \mathrm{z}$ $513.3047[\mathrm{M}+\mathrm{Na}]^{+}$, calc. $m / z 513.3038$ for $\mathrm{C}_{24} \mathrm{H}_{50} \mathrm{NaO}_{6} \mathrm{Si}_{2}$.
Benzyl $\quad(2 E, 4 R)-4-[[3,6-d i d e o x y-2-O-[(5 R)-5-[(2,4-d i-O-t e r t-$ butyldimethylsilyl-3,6-dideoxy- $\alpha$-L-arabino-hexopyranosyl)oxy]1-oxohexyl]- $\alpha$-L-arabino-hexopyranosyl]oxy]-2-pentenoate \& benzyl $\quad(2 E, 4 R)-4-[[3,6$-dideoxy-4-O-[(5R)-5-[(2,4-di-O-tertbutyldi-methylsilyl-3,6-dideoxy- $\alpha$-L-arabino-hexopyranosyl)oxy]-1oxohexyl]- $\alpha$-L-arabino-hexopyranosyl]oxy]-2-pentenoate. A solution of (5R)-5-[(2,4-di-O-tert-butyldimethylsilyl-3,6-dideoxy- $\alpha$-Larabino-hexopyranosyl)oxy]-hexanoic acid (12, $5.0 \mathrm{mg}$, $10.2 \mu \mathrm{mol})$ in dry dichloromethane $(0.5 \mathrm{~mL})$ at $0{ }^{\circ} \mathrm{C}$ was treated with 4-dimethylaminopyridine (DMAP, $2.5 \mathrm{mg}$, $20.4 \mu \mathrm{mol})$ and 1-ethyl-3-(3-dimethylaminopropyl) carbodiimide hydrochloride (EDC $\mathrm{HCl}, 3.9 \mathrm{mg}, 20.4 \mu \mathrm{mol}$ ). After stirring for 5 minutes a solution of benzyl $(2 E, 4 R)-4$-[(3,6-dideoxy$\alpha$-L-arabino-hexopyranosyl)oxy]-2-pentenoate (11a, $6.9 \mathrm{mg}$, $20.4 \mu \mathrm{mol})$ in dry dichloromethane $(0.5 \mathrm{~mL})$ was added. After $2 \mathrm{~h}$ at $0{ }^{\circ} \mathrm{C}$, the solution was concentrated under reduced pressure and the residue was fractionated by column chromatography on silica gel using a stepwise gradient from $10 \%$ to $30 \%(\mathrm{v} / \mathrm{v})$ ethyl acetate in hexane as eluent to afford the 2-linked benzyl $(2 E, 4 R)-4$-[[3,6-dideoxy-2-O-[(5R)-5-[(2,4-di-Otert-butyldimethylsilyl-3,6-dideoxy- $\alpha$-L-arabino-hexopyranosyl) oxy]-1-oxohexyl]- $\alpha$-L-arabino-hexopyranosyl]oxy]-2-pentenoate (2.1 $\mathrm{mg}, 2.57 \mu \mathrm{mol}, 25 \%$ yield) and the 4-linked benzyl $(2 E, 4 R)$ 4-[[3,6-dideoxy-4-O-[(5R)-5-[(2,4-di-O-tert-butyldimethylsilyl-3,6dideoxy- $\alpha$-L-arabino-hexopyranosyl)oxy]-1-oxohexyl]- $\alpha$-L-arabinohexopyranosyl]oxy]-2-pentenoate $(2.6 \mathrm{mg}, 3.18 \mu \mathrm{mol}, 31 \%$ yield) as colourless oils.

Benzyl $\quad(2 E, 4 R)-4-[[3,6$-dideoxy-2-O-[(5R)-5-[(2,4-di-O-tertbutyldimethylsilyl-3,6-dideoxy- $\alpha$-L-arabino-hexopyranosyl)oxy]1-oxohexyl]- $\alpha$-L-arabino-hexopyranosyl] oxy]-2-pentenoate. $\quad{ }^{1} \mathrm{H}$ NMR (400 MHz, CD $30 D) \delta 0.08(12 \mathrm{H}, \mathrm{s}), 0.90(9 \mathrm{H}, \mathrm{s}), 0.92(9 \mathrm{H}$, s), $1.12(3 \mathrm{H}, \mathrm{d}, J=6.0 \mathrm{~Hz}), 1.16(3 \mathrm{H}, \mathrm{d}, J=6.4 \mathrm{~Hz}), 1.17(3 \mathrm{H}, \mathrm{d}$, $J=6.1 \mathrm{~Hz}), 1.29(3 \mathrm{H}, \mathrm{d}, J=6.5 \mathrm{~Hz}), 1.55(2 \mathrm{H}, \mathrm{m}), 1.78(5 \mathrm{H}, \mathrm{m})$, $2.02(1 \mathrm{H}, \mathrm{m}), 2.40(2 \mathrm{H}, \mathrm{t}, J=7.0 \mathrm{~Hz}), 3.42(1 \mathrm{H}, \mathrm{m}), 3.63(3 \mathrm{H}$, $\mathrm{m}), 3.79(2 \mathrm{H}, \mathrm{m}), 4.44(1 \mathrm{H}, \mathrm{m}), 4.54(1 \mathrm{H}, \mathrm{s}), 4.76(1 \mathrm{H}, \mathrm{s}), 4.86$ (1H, s.br), 5.19 (2H, s), $6.08(1 \mathrm{H}, \mathrm{d}, J=15.3 \mathrm{~Hz}), 6.98(1 \mathrm{H}, \mathrm{dd}$, $J=15.7 \mathrm{~Hz}, J=5.3 \mathrm{~Hz}), 7.36(5 \mathrm{H}, \mathrm{m})$; ESI-(+)-HR-MS: obs. $\mathrm{m} / \mathrm{z}$ $831.4512[\mathrm{M}+\mathrm{Na}]^{+}$, calc. $m / z 831.4504$ for $\mathrm{C}_{42} \mathrm{H}_{72} \mathrm{ONaO}_{11} \mathrm{Si}_{2}$.

Benzyl $\quad(2 E, 4 R)-4-[[3,6-d i d e o x y-4-O-[(5 R)-5-[(2,4-d i-O-t e r t-$ butyldimethylsilyl-3,6-dideoxy- $\alpha$-L-arabino-hexopyranosyl)oxy]1-oxohexyl]- $\alpha$-L-arabino-hexopyranosyl]oxy]-2-pentenoate. ${ }^{1} \mathrm{H}$ NMR (400 MHz, CD 3 OD) $\delta 0.07(12 \mathrm{H}, \mathrm{s}), 0.90$ (9H, s), 0.93 (9H, s), $1.07(3 \mathrm{H}, \mathrm{d}, J=6.4 \mathrm{~Hz}), 1.11(3 \mathrm{H}, \mathrm{d}, J=5.9 \mathrm{~Hz}), 1.17(3 \mathrm{H}, \mathrm{d}$, $J=6.0 \mathrm{~Hz}), 1.29(3 \mathrm{H}, \mathrm{d}, J=6.4 \mathrm{~Hz}), 1.53(2 \mathrm{H}, \mathrm{m}), 1.67(1 \mathrm{H}, \mathrm{m})$, $1.80(4 \mathrm{H}, \mathrm{m}), 2.06(1 \mathrm{H}, \mathrm{dt}, J=12.9 \mathrm{~Hz}, J=3.3 \mathrm{~Hz}), 2.36(2 \mathrm{H}$, $\mathrm{m}), 3.64(2 \mathrm{H}, \mathrm{m}), 3.78(4 \mathrm{H}, \mathrm{m}), 4.44(1 \mathrm{H}, \mathrm{m}), 4.54(1 \mathrm{H}, \mathrm{s}), 4.72$ $(1 \mathrm{H}, \mathrm{s}), 4.85(1 \mathrm{H}, \mathrm{m}), 5.19(2 \mathrm{H}, \mathrm{s}), 6.06(2 \mathrm{H}, \mathrm{d}, J=15.2 \mathrm{~Hz})$, $6.99(1 \mathrm{H}, \mathrm{dd}, J=15.4 \mathrm{~Hz}, J=5.7 \mathrm{~Hz}), 7.36(5 \mathrm{H}, \mathrm{m})$; ESI(+)-HR-MS: obs. $m / z 831.4515[\mathrm{M}+\mathrm{Na}]^{+}$, calc. $m / z 831.4504$ for $\mathrm{C}_{42} \mathrm{H}_{72} \mathrm{ONaO}_{11} \mathrm{Si}_{2}$.

Benzyl $\quad(2 E, 5 R)-5-[[3,6$-dideoxy-2-O-[(5R)-5-[(2,4-di-O-tertbutyldimethylsilyl-3,6-dideoxy- $\alpha$-L-arabino-hexopyranosyl)oxy]1-oxohexyl]- $\alpha$-L-arabino-hexopyranosyl]oxy]-2-hexenoate \& Benzyl $(2 E, 5 R)-5$-[[3,6-dideoxy-4-O-[(5R)-5-[(2,4-di-O-tert-butyldi-methylsilyl-3,6-dideoxy- $\alpha$-L-arabino-hexopyranosyl)oxy]-1-oxohexyl]- $\alpha$-Larabino-hexo-pyranosyl]oxy]-2-hexenoate. A solution of (5R)-5- 
[(2,4-di-O-tert-butyldimethylsilyl-3,6-dideoxy- $\alpha$-L-arabino-hexopyranosyl)oxy]-hexanoic acid $(\mathbf{1 2}, 4.5 \mathrm{mg}, 9.2 \mu \mathrm{mol})$ in dry dichloromethane $(0.5 \mathrm{~mL})$ at $0{ }^{\circ} \mathrm{C}$ was treated with 4 -dimethylaminopyridine (DMAP, $2.3 \mathrm{mg}, 18.4 \mu \mathrm{mol})$ and 1-ethyl-3-(3dimethylaminopropyl) carbodiimide hydrochloride (EDC $\mathrm{HCl}, 3.5 \mathrm{mg}, 18.4 \mu \mathrm{mol})$. After stirring for 5 minutes a solution of benzyl $(2 E, 5 R)-5$-[(3,6-dideoxy- $\alpha$-L-arabino-hexopyranosyl)oxy]-2-hexenoate $(\mathbf{1 1 b}, 6.5 \mathrm{mg}, 18.4 \mu \mathrm{mol})$ in dry dichloromethane $(0.5 \mathrm{~mL})$ was added. After $2 \mathrm{~h}$ at $0{ }^{\circ} \mathrm{C}$ the solution was concentrated under reduced pressure and the residue fractionated by column chromatography on silica gel using a stepwise gradient from $10 \%$ to $30 \%(\mathrm{v} / \mathrm{v})$ ethyl acetate in hexane as eluent to afford the 2-linked benzyl $(2 E, 5 R)-5-[[3,6-$ dideoxy-2-O-[(5R)-5-[(2,4-di-O-tert-butyldimethyl-silyl-3,6-dideoxy$\alpha$-L-arabino-hexopyranosyl)oxy]-1-oxohexyl]- $\alpha$-L-arabino-hexopyranosyl]oxy]-2-hexenoate (2.4 mg, $2.89 \mu \mathrm{mol}, 31 \%$ yield) and the 4-linked benzyl $(2 E, 5 R)-5$-[[3,6-dideoxy-4-O-[(5R)-5-[(2,4-di-Otert-butyldimethylsilyl-3,6-dideoxy- $\alpha$-L-arabino-hexopyranosyl) oxy]-1-oxohexyl]- $\alpha$-L-arabino-hexopyranosyl]oxy]-2-hexenoate (1.1 mg, $1.32 \mu \mathrm{mol}, 14 \%$ yield) as colourless oils.

Benzyl $\quad(2 E, 5 R)-5$-[[3,6-dideoxy-2-O-[(5R)-5-[(2,4-di-O-tertbutyldimethylsilyl-3,6-dideoxy- $\alpha$-L-arabino-hexopyranosyl)oxy]1-oxohexyl]- $\alpha$-L-arabino-hexopyranosyl] oxy]-2-hexenoate. $\quad{ }^{1} \mathrm{H}$ NMR (400 MHz, CD $30 D) \delta 0.08(12 \mathrm{H}, \mathrm{s}), 0.90(9 \mathrm{H}, \mathrm{s}), 0.92(9 \mathrm{H}$, s), $1.12(3 \mathrm{H}, \mathrm{d}, J=6.0 \mathrm{~Hz}), 1.17(6 \mathrm{H}, \mathrm{m}), 1.46-1.89(9 \mathrm{H}, \mathrm{m})$, $1.99(1 \mathrm{H}, \mathrm{dt}, J=13.5 \mathrm{~Hz}, J=3.5 \mathrm{~Hz}), 2.40(1 \mathrm{H}, \mathrm{t}, J=6.6 \mathrm{~Hz})$, $2.46(1 \mathrm{H}, \mathrm{t}, J=6.6 \mathrm{~Hz}), 3.42(1 \mathrm{H}, \mathrm{m}), 3.65(3 \mathrm{H}, \mathrm{m}), 3.78(2 \mathrm{H}$, $\mathrm{m}), 3.80(1 \mathrm{H}, \mathrm{s}), 3.94(1 \mathrm{H}, \mathrm{q}, J=6.1 \mathrm{~Hz}), 4.54(1 \mathrm{H}, \mathrm{s}), 4.71(1 \mathrm{H}$, s), 4.78 (1H, s.br), $5.17(2 \mathrm{H}, \mathrm{s}), 5.98(1 \mathrm{H}, \mathrm{d}, J=15.7 \mathrm{~Hz}), 7.05$ (1H, dt, $J=15.5 \mathrm{~Hz}, J=7.8 \mathrm{~Hz}), 7.34(5 \mathrm{H}, \mathrm{m})$; ESI-(+)-HR-MS: obs. $m / z \quad 845.4670[\mathrm{M}+\mathrm{Na}]^{+}$, calc. $m / z 845.4662$ for $\mathrm{C}_{43} \mathrm{H}_{74} \mathrm{ONaO}_{11} \mathrm{Si}_{2}$.

Benzyl $\quad(2 E, 5 R)-5$-[[3,6-dideoxy-4-O-[(5R)-5-[(2,4-di-O-tertbutyldimethylsilyl-3,6-dideoxy- $\alpha$-L-arabino-hexopyranosyl)oxy]1-oxohexyl]- $\alpha$-L-arabino-hexopyranosyl] oxy]-2-hexenoate. $\quad{ }^{1} \mathrm{H}$ NMR (400 MHz, CD 3 OD) $\delta 0.08(12 \mathrm{H}, \mathrm{s}), 0.90(9 \mathrm{H}, \mathrm{s}), 0.92(9 \mathrm{H}$, s), $1.07(3 \mathrm{H}, \mathrm{d}, J=6.2 \mathrm{~Hz}), 1.10(3 \mathrm{H}, \mathrm{d}, J=6.1 \mathrm{~Hz}), 1.17(3 \mathrm{H}, \mathrm{d}, J$ $=5.3 \mathrm{~Hz}), 1.19(3 \mathrm{H}, \mathrm{d}, J=5.1 \mathrm{~Hz}), 1.46(2 \mathrm{H}, \mathrm{m}), 1.54(2 \mathrm{H}, \mathrm{m})$, $1.63(1 \mathrm{H}, \mathrm{m}), 1.79(2 \mathrm{H}, \mathrm{m}), 2.02(1 \mathrm{H}, \mathrm{dt}, J=11.9 \mathrm{~Hz}, J=4.1 \mathrm{~Hz})$, $2.27(2 \mathrm{H}, \mathrm{m}), 2.45(2 \mathrm{H}, \mathrm{t}, J=7.1 \mathrm{~Hz}), 3.63(2 \mathrm{H}, \mathrm{m}), 3.72(1 \mathrm{H}, \mathrm{s}$. br), $3.79(3 \mathrm{H}, \mathrm{m}), 3.95(1 \mathrm{H}, \mathrm{m}), 4.53(1 \mathrm{H}, \mathrm{s}), 4.68(1 \mathrm{H}, \mathrm{s}), 4.84$ $(1 \mathrm{H}, \mathrm{m}), 5.19(2 \mathrm{H}, \mathrm{s}), 5.98(1 \mathrm{H}, \mathrm{d}, J=15.8 \mathrm{~Hz}), 7.07$ (1H, dt, $J=$ $14.4 \mathrm{~Hz}, J=7.7 \mathrm{~Hz}$ ), 7.31 (5H, m); ESI-(+)-HR-MS: obs. $\mathrm{m} / z$ $845.4675[\mathrm{M}+\mathrm{Na}]^{+}$, calc. $m / z$ 845.4662 for $\mathrm{C}_{43} \mathrm{H}_{74} \mathrm{ONaO}_{11} \mathrm{Si}_{2}$.

(4R)-4-[[3,6-Dideoxy-2-O-[(5R)-5-[(2,4-di-O-tert-butyldimethylsilyl-3,6-dideoxy- $\alpha$-L-arabino-hexopyranosyl)oxy]-1-oxohexyl]- $\alpha$-Larabino-hexopyranosyl]oxy]-pentanoic acid. A solution of benzyl $(2 E, 4 R)-4-[[3,6$-dideoxy-2-O-[(5R)-5-[(2,4-di-O-tert-butyldimethylsilyl-3,6-dideoxy- $\alpha$-L-arabino-hexopyranosyl)oxy]-1-oxohexyl]$\alpha$-L-arabino-hexopyranosyl]oxy]-2-pentenoate $(2.6 \mathrm{mg}, 3.21 \mu \mathrm{mol})$ in methanol $(0.5 \mathrm{~mL})$ was treated with $10 \mathrm{~mol} \%$ palladium on carbon $(10 \mathrm{mg})$ and hydrogenated under $\mathrm{H}_{2}$ atmosphere (1 atm). After stirring for $4 \mathrm{~h}$ the catalyst was removed by filtration over Celite and the product was obtained without further purification by concentration under reduced pressure to afford $(4 R)-4-[[3,6-$ dideoxy-2-O-[(5R)-5-[(2,4-di-O-tert-butyldimethylsilyl-3,6-dideoxy-
$\alpha$-L-arabino-hexopyranosyl)oxy]-1-oxohexyl]- $\alpha$-L-arabino-hexopyranosyl]oxy]-pentanoic acid (2.1 mg, $2.91 \mu \mathrm{mol}, 90 \%$ yield) as a colourless oil. ${ }^{1} \mathrm{H}$ NMR (400 MHz, $\left.\mathrm{CD}_{3} \mathrm{OD}\right) \delta 0.08(12 \mathrm{H}, \mathrm{s}), 0.90$ (9H, s), $0.92(9 \mathrm{H}, \mathrm{s}), 1.12(3 \mathrm{H}, \mathrm{d}, J=6.1 \mathrm{~Hz}), 1.14(3 \mathrm{H}, \mathrm{d}, J=6.0$ $\mathrm{Hz}), 1.16(3 \mathrm{H}, \mathrm{d}, J=6.0 \mathrm{~Hz}), 1.18(3 \mathrm{H}, \mathrm{d}, J=6.1 \mathrm{~Hz}), 1.49(2 \mathrm{H}$, m), 1.62 (1H, m), $1.81(6 \mathrm{H}, \mathrm{m}), 2.04(1 \mathrm{H}, \mathrm{td}, J=12.2 \mathrm{~Hz}, J=4.0$ $\mathrm{Hz}), 2.36$ (4H, m), 3.63 (2H, m), 3.72 (1H, s.br), $3.82(3 \mathrm{H}, \mathrm{m})$, $4.54(1 \mathrm{H}, \mathrm{s}), 4.69(1 \mathrm{H}, \mathrm{s}), 4.88(1 \mathrm{H}, \mathrm{m}) ;{ }^{13} \mathrm{C} \mathrm{NMR}(100 \mathrm{MHz}$, $\left.\mathrm{CD}_{3} \mathrm{OD}\right) \delta-4.8(4 \mathrm{C}), 17.9,18.4,18.5,19.1,22.2,26.0$ (6C), 32.5, 32.9, 34.0, 34.6, 37.4, 37.7, 68.1, 69.3, 70.0, 71.0, 71.2, 71.4, 71.9, 72.1, 97.1, 97.7; ESI-(-)-HR-MS: obs. $m / z$ 719.4237 [M $\mathrm{H}]^{-}$, calc. $m / z 719.4227$ for $\mathrm{C}_{35} \mathrm{H}_{67} \mathrm{O}_{11} \mathrm{Si}_{2}$.

$(4 R)-4$-[[3,6-Dideoxy-4-O-[(5R)-5-[(2,4-di-O-tert-butyldimethylsilyl-3,6-dideoxy- $\alpha$-L-arabino-hexopyranosyl)oxy]-1-oxohexyl]$\boldsymbol{\alpha}$-L-arabino-hexopyranosyl]oxy]-pentanoic acid. Benzyl $(2 E, 4 R)$ 4-[[3,6-dideoxy-4-O-[(5R)-5-[(2,4-di-O-tert-butyldimethylsilyl-3,6dideoxy- $\alpha$-L-arabino-hexopyranosyl)oxy]-1-oxohexyl]- $\alpha$-L-arabinohexopyranosyl]oxy]-2-pentenoate $(2.1 \mathrm{mg}, 2.60 \mu \mathrm{mol})$ was hydrogenated as described for the 2'-(asc-C6)-asc-C5 derivative to afford $(4 R)-4$-[[3,6-dideoxy-4-O-[(5R)-5-[(2,4-di-O-tert-butyldimethylsilyl-3,6-dideoxy- $\alpha$-L-arabino-hexopyranosyl)oxy]-1-oxohexyl]$\alpha$-L-arabino-hexopyranosyl]oxy]-pentanoic acid $(1.8 \mathrm{mg}, 2.50 \mu \mathrm{mol}$, $96 \%$ yield) as a colourless oil. ${ }^{1} \mathrm{H}$ NMR (400 MHz, $\left.\mathrm{CD}_{3} \mathrm{OD}\right) \delta 0.08$ (12H, s), 0.90 (9H, s), 0.93 (9H, s), $1.12(3 \mathrm{H}, \mathrm{d}, J=6.4 \mathrm{~Hz}), 1.14$ $(3 \mathrm{H}, \mathrm{d}, J=6.8 \mathrm{~Hz}), 1.18(3 \mathrm{H}, \mathrm{d}, J=5.8 \mathrm{~Hz}), 1.23(3 \mathrm{H}, \mathrm{d}, J=6.1 \mathrm{~Hz})$, $1.55(2 \mathrm{H}, \mathrm{m}), 1.68(1 \mathrm{H}, \mathrm{m}), 1.79(5 \mathrm{H}, \mathrm{m}), 1.90(1 \mathrm{H}, \mathrm{m}), 2.00(1 \mathrm{H}$, $\mathrm{m}), 2.25(1 \mathrm{H}, \mathrm{m}), 2.34(1 \mathrm{H}, \mathrm{m}), 2.40(2 \mathrm{H}, \mathrm{t}, J=7.0 \mathrm{~Hz}), 3.39(1 \mathrm{H}$, $\mathrm{m}), 3.66(3 \mathrm{H}, \mathrm{m}), 3.81(3 \mathrm{H}, \mathrm{m}), 4.54(1 \mathrm{H}, \mathrm{s}), 4.72(1 \mathrm{H}, \mathrm{s}), 4.78(1 \mathrm{H}$, $\mathrm{s}$ br); ${ }^{13} \mathrm{C}$ NMR (100 MHz, $\left.\mathrm{CD}_{3} \mathrm{OD}\right) \delta-4.8$ (4), 17.8, 18.3, 18.8, 19.0, 22.0, 26.0 (6), 33.0, 34.6, 34.6, 34.7, 37.1, 37.7, 68.5, 70.0, 70.4, 71.2, 71.3, 71.9, 72.2, 72.5, 94.1, 97.8; ESI-(-)-HR-MS: obs. $m / z 719.4241[\mathrm{M}-\mathrm{H}]^{-}$, calc. $m / z 719.4227$ for $\mathrm{C}_{35} \mathrm{H}_{67} \mathrm{O}_{11} \mathrm{Si}_{2}$.

(5R)-5-[[3,6-Dideoxy-2-O-[(5R)-5-[(2,4-di-O-tert-butyldimethylsilyl-3,6-dideoxy- $\alpha$-L-arabino-hexopyranosyl)oxy]-1-oxohexyl]- $\alpha$-Larabino-hexopyranosyl] oxy]-hexanoic-acid. Benzyl $(2 E, 5 R)$ 5-[[3,6-dideoxy-2-O-[(5R)-5-[(2,4-di-O-tert-butyldimethylsilyl-3,6dideoxy- $\alpha$-L-arabino-hexopyranosyl)oxy]-1-oxohexyl]- $\alpha$-L-arabinohexopyranosyl]oxy]-2-hexenoate $(2.4 \mathrm{mg}, 2.89 \mu \mathrm{mol})$ was hydrogenated as described for the 2'-(asc-C6)-asc-C5 derivative to afford (5R)-5-[[3,6-dideoxy-2-O-[(5R)-5-[(2,4-di-O-tert-butyldimethylsilyl-3,6-dideoxy- $\alpha$-L-arabino-hexopyranosyl)oxy]-1-oxohexyl]- $\alpha$-L-arabino-hexopyranosyl]oxy]-hexanoic acid $(1.5 \mathrm{mg}$, $2.04 \mu \mathrm{mol}, 70 \%$ yield) as a colourless oil. ${ }^{1} \mathrm{H}$ NMR $(400 \mathrm{MHz}$, $\left.\mathrm{CD}_{3} \mathrm{OD}\right) \delta 0.08(12 \mathrm{H}, \mathrm{s}), 0.90(9 \mathrm{H}, \mathrm{s}), 0.92(9 \mathrm{H}, \mathrm{s}), 1.12(3 \mathrm{H}, \mathrm{d}$, $J=5.8 \mathrm{~Hz}), 1.13(3 \mathrm{H}, \mathrm{d}, J=5.8 \mathrm{~Hz}), 1.17(3 \mathrm{H}, \mathrm{d}, J=6.0 \mathrm{~Hz})$, $1.22(3 \mathrm{H}, \mathrm{d}, J=6.1 \mathrm{~Hz}), 1.59(6 \mathrm{H}, \mathrm{m}), 1.83(5 \mathrm{H}, \mathrm{m}), 2.00(1 \mathrm{H}$, $\mathrm{m}), 2.21(2 \mathrm{H}, \mathrm{m}), 2.40(2 \mathrm{H}, \mathrm{m}), 3.39(1 \mathrm{H}, \mathrm{m}), 3.66(3 \mathrm{H}, \mathrm{m})$, $3.80(3 \mathrm{H}, \mathrm{m}), 4.54(1 \mathrm{H}, \mathrm{s}), 4.71(1 \mathrm{H}, \mathrm{s}), 4.78(1 \mathrm{H}, \mathrm{s.br}) ;{ }^{13} \mathrm{C}$ NMR (100 MHz, CD $\left.{ }_{3} \mathrm{OD}\right) \delta-4.9$ (4C), 17.9, 18.3 (2C), 18.9, 22.1 , 23.6, 26.0 (6C), 32.7, 34.8, 37.7, 37.7, 38.1, 38.5, 67.8, 69.3, 69.9, 70.9, 71.1, 71.3, 72.1, 72.4, 97.3, 97.7; ESI(-)-HR-MS: obs. $m / z 733.4399[\mathrm{M}-\mathrm{H}]^{-}$, calc. $m / z 733.4384$ for $\mathrm{C}_{36} \mathrm{H}_{69} \mathrm{O}_{11} \mathrm{Si}_{2}$.

(5R)-5-[[3,6-Dideoxy-4-O-[(5R)-5-[(2,4-di-O-tert-butyldimethylsilyl-3,6-dideoxy- $\alpha$-L-arabino-hexopyranosyl)oxy]-1-oxohexyl]$\boldsymbol{\alpha}$-L-arabino-hexopyranosyl]oxy]-hexanoic acid. Benzyl $(2 E, 5 R)$ - 
5-[[3,6-dideoxy-4-O-[(5R)-5-[(2,4-di-O-tert-butyldimethylsilyl-3,6dideoxy- $\alpha$-L-arabino-hexopyranosyl)oxy]-1-oxohexyl]- $\alpha$-L-arabinohexopyranosyl]oxy]-2-hexenoate $(1.1 \mathrm{mg}, 1.32 \mu \mathrm{mol})$ was hydrogenated as described for the 2'-(asc-C6)-asc-C5 derivative to afford $\quad(5 R)-5$-[[3,6-dideoxy-4-O-[(5R)-5-[(2,4-di-O-tert-butyldimethylsilyl-3,6-dideoxy- $\alpha$-L-arabino-hexopyranosyl)oxy]-1-oxohexyl]$\alpha$-L-arabino-hexopyranosyl]oxy]-hexanoic acid $(0.9 \mathrm{mg}, 1.22 \mu \mathrm{mol}$, $92 \%$ yield) as a colourless oil. ${ }^{1} \mathrm{H}$ NMR $\left(400 \mathrm{MHz}, \mathrm{CD}_{3} \mathrm{OD}\right) \delta 0.08$ $(12 \mathrm{H}, \mathrm{s}), 0.90(9 \mathrm{H}, \mathrm{s}), 0.92(9 \mathrm{H}, \mathrm{s}), 1.12(9 \mathrm{H}, \mathrm{m}), 1.14(9 \mathrm{H}, \mathrm{d}, J=$ $6.1 \mathrm{~Hz}), 1.17(3 \mathrm{H}, \mathrm{d}, J=6.1 \mathrm{~Hz}), 1.49(2 \mathrm{H}, \mathrm{m}), 1.62(4 \mathrm{H}, \mathrm{m}), 1.76$ $(3 \mathrm{H}, \mathrm{m}), 1.85(2 \mathrm{H}, \mathrm{m}), 2.03(1 \mathrm{H}, \mathrm{m}), 2.20(2 \mathrm{H}, \mathrm{t}, J=7.3 \mathrm{~Hz}), 2.35$ $(2 \mathrm{H}, \mathrm{m}), 3.62(2 \mathrm{H}, \mathrm{m}), 3.71(1 \mathrm{H}, \mathrm{s} \mathrm{br}), 3.80(3 \mathrm{H}, \mathrm{m}), 3.87(1 \mathrm{H}, \mathrm{m})$, $4.54(1 \mathrm{H}, \mathrm{s}), 4.68(1 \mathrm{H}, \mathrm{s}), 4.86(1 \mathrm{H}, \mathrm{m}) ;{ }^{13} \mathrm{C}$ NMR $(100 \mathrm{MHz}$, $\left.\mathrm{CD}_{3} \mathrm{OD}\right) \delta-4.9$ (4C), 17.9, 18.3, 18.6, 18.9, 22.1, 23.6, 26.0 (6C), 32.7, 34.8, 37.7, 37.7, 38.1, 38.5, 67.8, 69.3, 69.9, 70.9, 71.1, 71.3, 72.1, 72.4, 97.3, 97.7; ESI-(-)-HR-MS: obs. $m / z 733.4392[\mathrm{M}-\mathrm{H}]^{-}$, calc. $m / z 733.4384$ for $\mathrm{C}_{36} \mathrm{H}_{69} \mathrm{O}_{11} \mathrm{Si}_{2}$.

(4R)-4-[[3,6-Dideoxy-2-O-[(5R)-5-[(3,6-dideoxy- $\alpha$-L-arabino-hexopyranosyl)oxy]-1-oxohexyl]- $\alpha$-L-arabino-hexopyranosyl]oxy]-pentanoic acid (2'-(asc-C6)-asc-C5, 7). In a $2 \mathrm{ml}$ polypropylene cryovial a solution of $(4 R)-4-[[3,6$-dideoxy-2-O-[(5R)-5-[(2,4-di-O-tertbutyldimethylsilyl-3,6-dideoxy- $\alpha$-L-arabino-hexo-pyranosyl)oxy]1-oxohexyl]- $\alpha$-L-arabino-hexopyranosyl]oxy]-pentanoic acid $(2.1 \mathrm{mg}, 2.91 \mu \mathrm{mol})$ in dry tetrahydrofuran $(500 \mu \mathrm{L})$ was treated with dry pyridine $(40 \mu \mathrm{L}, 500 \mu \mathrm{mol})$ and Olah's reagent $(70 \%$ $(\mathrm{w} / \mathrm{w})$ hydrogen fluoride in pyridine, $13 \mu \mathrm{l}, 500 \mu \mathrm{mol}$ ). After stirring for 10 days the reaction was quenched by transfer into a $4 \mathrm{ml}$ glass vial and addition of saturated aqueous sodium hydrogencarbonate solution $(0.1 \mathrm{~mL})$, dried over sodium sulphate, filtered, and concentrated under reduced pressure. The residue was fractionated by solid phase extraction (SPE) on a $100 \mathrm{mg}$ reverse phase C18ec cartridge (Chromabond, Macherey Nagel) using a stepwise gradient of methanol in water $(0-100 \%$ in $10 \%$ steps, $\mathrm{v} / \mathrm{v})$ as eluent to afford $(4 R)-4-[[3,6-$ dideoxy-2-O-[(5R)-5-[(3,6-dideoxy- $\alpha$-L-arabino-hexopyranosyl)oxy]1-oxohexyl]- $\alpha$-L-arabino-hexopyranosyl]oxy]-pentanoic acid (7, $0.5 \mathrm{mg}, 1.02 \mu \mathrm{mol}, 35 \%$ yield) as a colourless oil identical to the natural product from C. nigoni. ${ }^{1} \mathrm{H}$ NMR $\left(400 \mathrm{MHz}, \mathrm{CD}_{3} \mathrm{OD}\right)$ $\delta 1.14(3 \mathrm{H}, \mathrm{d}, J=6.1 \mathrm{~Hz}), 1.14(3 \mathrm{H}, \mathrm{d}, 6.1 \mathrm{~Hz}), 1.23(3 \mathrm{H}, \mathrm{d}, J=$ $6.1 \mathrm{~Hz}), 1.23(3 \mathrm{H}, \mathrm{d}, J=6.1 \mathrm{~Hz}), 1.56(2 \mathrm{H}, \mathrm{m}), 1.70(1 \mathrm{H}, \mathrm{m}), 1.77$ $(1 \mathrm{H}, \mathrm{ddd}, J=13.2 \mathrm{~Hz}, J=11.1 \mathrm{~Hz}, J=3.0 \mathrm{~Hz}), 1.80(3 \mathrm{H}, \mathrm{m}), 1.90$ $(1 \mathrm{H}, \mathrm{ddd}, J=13.4 \mathrm{~Hz}, J=11.8 \mathrm{~Hz}, J=3.4 \mathrm{~Hz}), 1.96(1 \mathrm{H}, \mathrm{dt}, J=$ $13.2 \mathrm{~Hz}, J=3.7 \mathrm{~Hz}), 2.01(1 \mathrm{H}, \mathrm{dt}, J=13.0 \mathrm{~Hz}, J=3.8 \mathrm{~Hz}), 2.34$ $(1 \mathrm{H}, \mathrm{m}), 2.37(1 \mathrm{H}, \mathrm{m}), 2.39(2 \mathrm{H}, \mathrm{dt}, J=3.2 \mathrm{~Hz}, J=7.3 \mathrm{~Hz}), 3.40$ $(\mathrm{ddd}, J=11.4 \mathrm{~Hz}, J=9.6 \mathrm{~Hz}, J=4.4 \mathrm{~Hz}), 3.52(1 \mathrm{H}, \mathrm{ddd}, J=11.2$ $\mathrm{Hz}, J=9.5 \mathrm{~Hz}, J=4.4 \mathrm{~Hz}), 3.62(1 \mathrm{H}, \mathrm{dq}, J=9.3 \mathrm{~Hz}, J=6.2 \mathrm{~Hz})$, $3.71(1 \mathrm{H}, \mathrm{dq}, J=9.6 \mathrm{~Hz}, J=6.2 \mathrm{~Hz}), 3.73(1 \mathrm{H}, \mathrm{s.br}), 3.81(1 \mathrm{H}$, $\mathrm{m}), 3.83(1 \mathrm{H}, \mathrm{m}), 4.65(1 \mathrm{H}, \mathrm{s}), 4.71(1 \mathrm{H}, \mathrm{s}), 4.79(1 \mathrm{H}, \mathrm{s} . \mathrm{br}) ;{ }^{13} \mathrm{C}$ NMR $\left(100 \mathrm{MHz}, \mathrm{CD}_{3} \mathrm{OD}\right) \delta 17.9,17.9,18.7,18.7,21.8,33.4$, 34.0, 34.6, 34.9, 35.1, 37.2, 68.2, 68.2, 70.1, 70.1, 70.9, 72.2, 72.2, 72.3, 94.1, 97.6 (Table S3†); ESI-(-)-HR-MS: obs. $\mathrm{m} / \mathrm{z}$ $491.2502[\mathrm{M}-\mathrm{H}]^{-}$, calc. $m / z 491.2498$ for $\mathrm{C}_{23} \mathrm{H}_{39} \mathrm{O}_{11}$.

(5R)-5-[[3,6-Dideoxy-2-O-[(5R)-5-[(3,6-dideoxy- $\alpha$-L-arabino-hexopyranosyl)oxy]-1-oxohexyl]- $\alpha$-L-arabino-hexopyranosyl] oxy]-hexanoic acid (2'-(asc-C6)-asc-C6, 8). (5R)-5-[[3,6-Dideoxy-2-O-[(5R)-5[(2,4-di-O-tert-butyldimethylsilyl-3,6-dideoxy- $\alpha$-L-arabino-hexo- pyranosyl)oxy]-1-oxohexyl]- $\alpha$-L-arabino-hexopyranosyl]oxy]-hexanoic acid $(1.5 \mathrm{mg}, 2.03 \mu \mathrm{mol})$ was treated as described for 7 to afford (5R)-5-[[3,6-dideoxy-2-O-[(5R)-5-[(3,6-dideoxy- $\alpha$-L-arabinohexopyranosyl)oxy]-1-oxohexyl]- $\alpha$-L-arabino-hexopyranosyl]oxy]hexanoic acid $(8,0.5 \mathrm{mg}, 0.99 \mu \mathrm{mol}, 49 \%$ yield $)$ as a colourless oil identical to the natural product from C. nigoni. ${ }^{1} \mathrm{H}$ NMR $\left(400 \mathrm{MHz}, \mathrm{CD}_{3} \mathrm{OD}\right) \delta 1.14(3 \mathrm{H}, \mathrm{d}, J=6.1 \mathrm{~Hz}), 1.14(3 \mathrm{H}, \mathrm{d}, 6.2$ $\mathrm{Hz}), 1.22(3 \mathrm{H}, \mathrm{d}, J=6.3 \mathrm{~Hz}), 1.22(3 \mathrm{H}, \mathrm{d}, J=6.3 \mathrm{~Hz}), 1.57(4 \mathrm{H}$, $\mathrm{m}), 1.65(1 \mathrm{H}, \mathrm{m}), 1.70(1 \mathrm{H}, \mathrm{m}), 1.76(1 \mathrm{H}, \mathrm{m}), 1.77(1 \mathrm{H}, \mathrm{ddd}, J=$ $13.3 \mathrm{~Hz}, J=11.2 \mathrm{~Hz}, J=3.1 \mathrm{~Hz}), 1.79(1 \mathrm{H}, \mathrm{m}), 1.88(1 \mathrm{H}, \mathrm{ddd}, J$ $=13.4 \mathrm{~Hz}, J=11.5 \mathrm{~Hz}, J=3.0 \mathrm{~Hz}), 1.95(1 \mathrm{H}, \mathrm{dt}, J=13.4 \mathrm{~Hz}, J=$ $3.8 \mathrm{~Hz}), 2.00(1 \mathrm{H}, \mathrm{dt}, J=13.2 \mathrm{~Hz}, J=3.6 \mathrm{~Hz}), 2.24(2 \mathrm{H}, \mathrm{t}, J=7.3$ $\mathrm{Hz}), 2.39(2 \mathrm{H}, \mathrm{dt}, J=3.1 \mathrm{~Hz}, J=7.3 \mathrm{~Hz}), 3.41(\mathrm{ddd}, J=11.3 \mathrm{~Hz}$, $J=9.7 \mathrm{~Hz}, J=4.7 \mathrm{~Hz}), 3.51(1 \mathrm{H}, \mathrm{ddd}, J=11.1 \mathrm{~Hz}, J=9.6 \mathrm{~Hz}, J=$ $4.6 \mathrm{~Hz}), 3.62(1 \mathrm{H}, \mathrm{dq}, J=9.5 \mathrm{~Hz}, J=6.3 \mathrm{~Hz}), 3.70(1 \mathrm{H}, \mathrm{dq}, J=$ $9.5 \mathrm{~Hz}, J=6.3 \mathrm{~Hz}), 3.72(1 \mathrm{H}, \mathrm{s.br}), 3.79(1 \mathrm{H}, \mathrm{m}), 3.80(1 \mathrm{H}, \mathrm{m})$, $4.65(1 \mathrm{H}, \mathrm{s}), 4.71(1 \mathrm{H}, \mathrm{s}), 4.78(1 \mathrm{H}, \mathrm{s.br}) ;{ }^{13} \mathrm{C}$ NMR $(100 \mathrm{MHz}$, $\left.\mathrm{CD}_{3} \mathrm{OD}\right) \delta 17.8,17.8,18.7,18.7,22.6,22.6,33.1,34.7,35.7$, $36.8, \quad 37.4,37.4,68.3,68.5,70.1,70.1,70.9,72.2,72.2$, 72.3, 94.3, 97.4 (Table S3†); ESI-(-)-HR-MS: obs. $m / z 505.2657$ $[\mathrm{M}-\mathrm{H}]^{-}$, calc. $m / z 505.2654$ for $\mathrm{C}_{24} \mathrm{H}_{41} \mathrm{O}_{11}$.

$(4 R)-4$-[[3,6-Dideoxy-4-O-[(5R)-5-[(3,6-dideoxy- $\alpha$-L-arabino-hexopyranosyl)oxy]-1-oxohexyl]- $\alpha$-L-arabino-hexopyranosyl]oxy]-pentanoic acid (4'-(asc-C6)-asc-C5, 13a)

$(4 R)$-4-[[3,6-Dideoxy-4-O-[(5R)-5-[(2,4-di-O-tert-butyldimethylsilyl3,6-dideoxy- $\alpha$-L-arabino-hexo-pyranosyl)oxy]-1-oxohexyl]- $\alpha$-L-arabinohexopyranosyl]oxy]-pentanoic acid $(1.8 \mathrm{mg}, 2.50 \mu \mathrm{mol})$ was treated as described for 7 to afford (4R)-4-[[3,6-dideoxy-4-O-[(5R)-5-[(3,6dideoxy- $\alpha$-L-arabino-hexopyranosyl)oxy]-1-oxohexyl]- $\alpha$-L-arabino-hexopyranosyl] oxy]-pentanoic acid (13a, $0.6 \mathrm{mg}, 1.22 \mu \mathrm{mol}, 49 \%$ yield) as a colourless oil. ${ }^{1} \mathrm{H}$ NMR $\left(400 \mathrm{MHz}, \mathrm{CD}_{3} \mathrm{OD}\right) \delta 1.13(3 \mathrm{H}$, $\mathrm{d}, J=6.2 \mathrm{~Hz}), 1.14(3 \mathrm{H}, \mathrm{d}, J=6.3 \mathrm{~Hz}), 1.16(3 \mathrm{H}, \mathrm{d}, J=6.2 \mathrm{~Hz}), 1.22$ $(3 \mathrm{H}, \mathrm{d}, J=6.2 \mathrm{~Hz}), 1.56(2 \mathrm{H}, \mathrm{m}), 1.67(1 \mathrm{H}, \mathrm{m}), 1.76(1 \mathrm{H}, \mathrm{ddd}, J=$ $13.1 \mathrm{~Hz}, J=11.1 \mathrm{~Hz}, J=3.0 \mathrm{~Hz}), 1.79(1 \mathrm{H}, \mathrm{m}), 1.80(2 \mathrm{H}, \mathrm{m}), 1.85$ $(1 \mathrm{H}, \mathrm{ddd}, J=13.3 \mathrm{~Hz}, J=11.3 \mathrm{~Hz}, J=3.0 \mathrm{~Hz}), 1.95(1 \mathrm{H}, \mathrm{dt}, J=13.0$ $\mathrm{Hz}, J=3.8 \mathrm{~Hz}), 2.04(1 \mathrm{H}, \mathrm{dt}, J=12.9 \mathrm{~Hz}, J=4.2 \mathrm{~Hz}), 2.35(2 \mathrm{H}, \mathrm{m})$, $2.40(2 \mathrm{H}, \mathrm{t}, J=7.4 \mathrm{~Hz}), 3.51(1 \mathrm{H}, \mathrm{ddd}, J=11.0 \mathrm{~Hz}, J=9.5 \mathrm{~Hz}, J=$ $4.6 \mathrm{~Hz}), 3.61(1 \mathrm{H}, \mathrm{dq}, J=9.4 \mathrm{~Hz}, J=6.2 \mathrm{~Hz}), 3.72(1 \mathrm{H}, \mathrm{s.br}), 3.73$ (1H, s.br), $3.80(1 \mathrm{H}, \mathrm{m}), 3.85(1 \mathrm{H}, \mathrm{m}), 3.85(1 \mathrm{H}, \mathrm{dq}, J=9.7 \mathrm{~Hz}, J=$ $6.2 \mathrm{~Hz}), 4.64(1 \mathrm{H}, \mathrm{s}), 4.69(1 \mathrm{H}, \mathrm{s}), 4.87(1 \mathrm{H}, \mathrm{ddd}, J=11.3 \mathrm{~Hz}, J=$ $9.7 \mathrm{~Hz}, J=4.5 \mathrm{~Hz}) ;{ }^{13} \mathrm{C} \mathrm{NMR}\left(100 \mathrm{MHz}, \mathrm{CD}_{3} \mathrm{OD}\right) \delta 17.8,18.5,18.5$, 18.5, 22.3, 31.4, 33.2, 33.2, 34.8, 35.6, 37.3, 68.2, 68.2, 69.6, 69.6, 71.1, 71.1, 71.7, 71.9, 97.2, 97.4 (Table S3†); ESI-(-)-HR-MS: obs. $m / z 491.2503[\mathrm{M}-\mathrm{H}]^{-}$, calc. $m / z 491.2498$ for $\mathrm{C}_{23} \mathrm{H}_{39} \mathrm{O}_{11}$.

(5R)-5-[[3,6-Dideoxy-4-O-[(5R)-5-[(3,6-dideoxy- $\alpha$-L-arabino-hexopyranosyl)oxy]-1-oxohexyl]- $\alpha$-L-arabino-hexopyranosyl] oxy]-hexanoic acid (4'-(asc-C6)-asc-C6, 13b). (5R)-5-[[3,6-Dideoxy-4-O[(5R)-5-[(2,4-di-O-tert-butyldimethylsilyl-3,6-dideoxy- $\alpha$-L-arabinohexo-pyranosyl)oxy]-1-oxohexyl]- $\alpha$-L-arabino-hexopyranosyl]oxy]hexanoic acid $(0.9 \mathrm{mg}, 1.28 \mu \mathrm{mol})$ was treated as described for 7 to afford (5R)-5-[[3,6-dideoxy-4-O-[(5R)-5-[(3,6-dideoxy- $\alpha$-Larabino-hexopyranosyl)oxy]-1-oxohexyl]- $\alpha$-L-arabino-hexopyranosyl]oxy]-hexanoic acid (13b, $0.2 \mathrm{mg}, 0.39 \mu \mathrm{mol}, 30 \%$ yield) as a colourless oil. ${ }^{1} \mathrm{H}$ NMR $\left(400 \mathrm{MHz}, \mathrm{CD}_{3} \mathrm{OD}\right) \delta 1.13(3 \mathrm{H}, \mathrm{d}, J=$ $6.2 \mathrm{~Hz}), 1.14(3 \mathrm{H}, \mathrm{d}, J=6.2 \mathrm{~Hz}), 1.14(3 \mathrm{H}, \mathrm{d}, J=6.2 \mathrm{~Hz}), 1.22$ 
(3H, d, $J=6.2 \mathrm{~Hz}), 1.57$ (4H, m), 1.67 (2H, m), 1.76 (1H, ddd, $J$ $=13.2 \mathrm{~Hz}, J=11.2 \mathrm{~Hz}, J=3.0 \mathrm{~Hz}), 1.77(1 \mathrm{H}, \mathrm{m}) 1.78(1 \mathrm{H}, \mathrm{m})$, $1.85(1 \mathrm{H}, \mathrm{ddd}, J=12.9 \mathrm{~Hz}, J=1.4 \mathrm{~Hz}, J=2.9 \mathrm{~Hz}), 1.95(1 \mathrm{H}, \mathrm{dt}, J$ $=13.2 \mathrm{~Hz}, J=3.9 \mathrm{~Hz}), 2.03(1 \mathrm{H}, \mathrm{dt}, J=12.8 \mathrm{~Hz}, J=4.0 \mathrm{~Hz}), 2.25$ $(2 \mathrm{H}, \mathrm{t}, J=7.2 \mathrm{~Hz}), 2.35(2 \mathrm{H}, \mathrm{dt}, J=5.2 \mathrm{~Hz}, J=7.2 \mathrm{~Hz}), 3.51(1 \mathrm{H}$, ddd, $J=11.2 \mathrm{~Hz}, J=9.4 \mathrm{~Hz}, J=4.5 \mathrm{~Hz}), 3.61(1 \mathrm{H}, \mathrm{dq}, J=9.5$ $\mathrm{Hz}, J=6.1 \mathrm{~Hz}), 3.72(2 \mathrm{H}, \mathrm{s.br}), 3.80(2 \mathrm{H}, \mathrm{m}), 3.86(1 \mathrm{H}, \mathrm{dq}, J=$ $9.7 \mathrm{~Hz}, J=6.2 \mathrm{~Hz}), 4.64(1 \mathrm{H}, \mathrm{s}), 4.69(1 \mathrm{H}, \mathrm{s}), 4.86(1 \mathrm{H}, \mathrm{ddd}, J=$ $11.4 \mathrm{~Hz}, J=9.7 \mathrm{~Hz}, J=4.6 \mathrm{~Hz}) ;{ }^{13} \mathrm{C} \mathrm{NMR}\left(100 \mathrm{MHz}, \mathrm{CD}_{3} \mathrm{OD}\right) \delta$ $17.9,18.7,18.7,18.7,22.6,22.6,32.9,34.8,35.8,36.8,37.6$, $37.6,67.9,68.0,69.5,69.5,71.0,71.3,72.1,72.1,97.3,97.3$ (Table S3 $\dagger$ ); ESI-(-)-HR-MS: obs. $m / z$ 505.2656 [M - H] $]^{-}$, calc. $m / z 505.2654$ for $\mathrm{C}_{24} \mathrm{H}_{41} \mathrm{O}_{11}$.

\section{Conflicts of interest}

There are no conflicts to declare.

\section{Acknowledgements}

Financial support by the Max Planck Society (MPG), the Jena School of Microbial Communication (JSMC), the Swiss National Science Foundation (SNSF-169700), and the University of Neuchâtel (UniNE) is gratefully acknowledged. We thank Dr Michael Reichelt (Department for Biochemistry, MPICE, Jena) for acquisition of the MS/MS precursor ion scan. All nematode strains were provided by the Caenorhabditis Genetics Center, which is funded by NIH Office of Research Infrastructure Programs (P40 OD010440). Open Access funding provided by the Max Planck Society.

\section{References}

1 S. H. von Reuss and F. C. Schroeder, Nat. Prod. Rep., 2015, 32, 994-1006.

2 F. C. Schroeder, Chem. Biol., 2015, 22, 7-16.

3 R. A. Butcher, Nat. Chem. Biol., 2017, 13, 577-586.

4 R. A. Butcher, Nat. Prod. Rep., 2017, 34, 472-477.

5 M. Viney and S. Harvey, PLoS Genet., 2017, 13, e1007046.

6 S. H. von Reuss, Chimia, 2018, 72, 297-303.

7 P. T. McGrath and I. Ruvinsky, Curr. Opin. Syst. Biol., 2019, 13, 23-30.

8 J. Y. Park, H.-J. Joo, S. Park and Y.-K. Paik, Int. J. Mol. Sci., 2019, 20, 3898.

9 A. Choe, S. H. von Reuss, D. Kogan, R. B. Gasser, E. G. Platzer, F. C. Schroeder and P. W. Sternberg, Curr. Biol., 2012, 22, 772-780.

10 S. H. von Reuss, N. Bose, J. Srinivasan, J. J. Yim, J. C. Judkins, P. W. Sternberg and F. C. Schroeder, J. Am. Chem. Soc., 2012, 134, 1817-1824.

11 X. Zhang, J. H. Noguez, Y. Zhou and R. A. Butcher, Methods Mol. Biol., 2013, 1068, 71-92.

12 S. H. von Reuss, F. Dolke and C. Dong, Anal. Chem., 2017, 89, 10570-10577.
13 C. Pungaliya, J. Srinivasan, B. W. Fox, R. U. Malik, A. H. Ludewig, P. W. Sternberg and F. C. Schroeder, Proc. Natl. Acad. Sci. U. S. A., 2009, 106, 7708-7713.

14 Y. Izrayelit, S. L. Robinette, N. Bose, S. H. von Reuss and F. C. Schroeder, ACS Chem. Biol., 2013, 8, 314-319.

15 A. B. Artyukhin, Y. K. Zhang, A. E. Akagi, O. Panda, P. W. Sternberg and F. C. Schroeder, J. Am. Chem. Soc., 2018, 140, 2841-2852.

16 K. A. Hollister, E. S. Conner, X. Zhang, M. Spell, G. M. Bernard, P. Patel, A. C. de Carvalho, R. A. Butcher and J. R. Ragains, Bioorg. Med. Chem., 2013, 21, 57545769.

17 C. Dong, D. K. Reilly, C. Bergame, F. Dolke, J. Srinivasan and S. H. von Reuss, J. Org. Chem., 2018, 83, 71097120.

18 A. Choe, T. Chuman, S. H. von Reuss, A. T. Dossey, J. Yim, R. Ajredini, A. A. Kolawa, F. Kaplan, H. T. Alborn, P. E. Teal, F. C. Schroeder, P. W. Sternberg and A. S. Edison, Proc. Natl. Acad. Sci. U. S. A., 2012, 109, 20949-20954.

19 C. P. Bergame, C. Dong, S. Sutour and S. H. von Reuss, Org. Lett., 2019, 21, 9889-9892.

20 R. A. Butcher, J. R. Ragains and J. Clardy, Org. Lett., 2009, 11, 3100-3103.

21 J. Srinivasan, S. H. von Reuss, N. Bose, A. Zaslaver, P. Mahanti, M. C. Ho, O. G. O'Doherty, A. S. Edison, P. W. Sternberg and F. C. Schroeder, PLoS Biol., 2012, 10, e1001237.

22 Y. Zhou, X. Zhang and R. A. Butcher, ACS Chem. Biol., 2019, 14, 50-57.

23 C. Dong, F. Dolke and S. H. von Reuss, Org. Biomol. Chem., 2016, 14, 7217-7225.

24 F. Dolke, C. Dong, S. Bandi, C. Paetz, G. Glauser and S. H. von Reuss, Org. Lett., 2019, 21, 5832-5837.

25 P.-Y. Jeong, M. Jung, Y.-H. Yim and Y.-K. Paik, Nature, 2005, 433, 541-545.

26 R. Martin, T. Schaefer, G. Theumer, E. V. Entchev, T. V. Kurzchalia and H.-J. Knoelker, Synthesis, 2009, 34883492.

27 R. R. Schmidt and J. Michel, Angew. Chem., Int. Ed. Engl., 1980, 19, 731-732.

28 M. Scholl, S. Ding, C. W. Lee and R. H. Grubbs, Org. Lett., 1999, 1, 953-956.

29 B. Neises and W. Steglich, Angew. Chem., Int. Ed. Engl., 1978, 17, 522-524.

30 Small Molecule identifier (SMID) see http://www.smid-db. org.

31 N. Bose, A. Ogawa, S. H. von Reuss, J. J. Yim, E. J. Ragsdale, R. J. Sommer and F. C. Schroeder, Angew. Chem., Int. Ed., 2012, 51, 12438-12443.

32 J. M. Falcke, N. Bose, A. B. Artyukhin, C. Rödelsperger, G. V. Markov, J. J. Yim, D. Grimm, M. H. Claassen, O. Panda, J. A. Baccile, Y. K. Zhang, H. H. Le, D. Jolic, F. C. Schroeder and R. J. Sommer, Cell Chem. Biol., 2018, 25, 787-796.e12.

33 T. Stiernagle, WormBook, 2006, vol. 11, pp. 1-11. 